This document is the accepted manuscript version of the following article:
Binz, C., \& Anadon, L. D. (2018). Unrelated diversification in latecomer contexts - the emergence of the Chinese solar photovoltaics industry. Environmental Innovation and Societal Transitions, $28,14-34$. https://doi.org/10.1016/j.eist.2018.03.005

This manuscript version is made available under the CC-BY-NC-ND 4.0

license http://creativecommons.org/1icenses/by-nc-nd/4.0/

\title{
Unrelated diversification in latecomer countries - The emergence of the Chinese solar photovoltaics industry
}

Christian Binz ${ }^{\mathrm{a}, \mathrm{b}, \mathrm{d}^{*}}$, Laura Diaz Anadon ${ }^{\mathrm{c}, \mathrm{d}}$

${ }^{\text {a }}$ Eawag - Swiss Federal Institute of Aquatic Science and Technology. Ueberlandstrasse 133, 8600 Duebendorf, Switzerland. *Corresponding author: christian.binz@eawag.ch

${ }^{\mathrm{b}}$ Centre for Innovation, Research and Competence in the Learning Economy (CIRCLE), Lund University, 22362 Lund, Sweden.

${ }^{\mathrm{c}}$ Department of Land Economy, University of Cambridge, Cambridge CB3 9EP, United Kingdom.1da24@cam.ac.uk

${ }^{\mathrm{d}}$ Belfer Center for Science and International Affairs, John F. Kennedy School of Government, Harvard University, Cambridge MA, 02138.

JEL: O33, Q55, F64

\begin{abstract}
New industries emerge in increasingly complex spatial patterns that challenge existing explanations of industrial path creation. In particular, the case of latecomer regions building up industries in fields that are unrelated to their previous industrial capabilities is not well understood in the literature. This paper aims to address this gap by expanding on an analytical framework that draws on innovation studies and catching-up literature to characterize unrelated diversification processes in latecomer contexts. A case study in the Chinese solar photovoltaics (PV) sector reveals an industry formation process that differs from traditional models of industry formation. The PV industry emerged from a highly internationalized entrepreneurial project in which Chinese latecomer firms directly mobilized knowledge, markets, investment and technology legitimacy developing outside China and combined them with the country's generic capabilities in mass-manufacturing. In some industries, globalization thus enables a new model of industrial path creation that heavily draws on extraregional system resources.
\end{abstract}

Keywords: unrelated diversification; cleantech; path creation; innovation system; solar photovoltaics; China 


\section{Introduction}

The question how new industries emerge and locate in specific places is gaining renewed interest by scholars and policy makers, not the least in 'cleantech' sectors like renewable energy, electric transportation or water recycling. The sustainability transition literature in particular has highlighted that the diffusion of 'cleaner' industries plays an important role in wider transition trajectories away from unsustainable production patterns (Markard et al., 2012). Still, to date our theoretical understanding of the industry formation process - in cleantech sectors and more broadly - remains limited at best (Martin, 2010). Existing theories have particular problems explaining why cleantech industries increasingly take root so quickly in latecomer countries like China, Brazil or India when the relevant knowledge, firms, (subsidized) markets, and value chains are already well established in industrialized countries (Binz et al., 2017; Fu et al., 2011; Lee and Lim, 2001; Schmidt and Huenteler, 2016).

To date, industry formation in latecomer regions is commonly understood as a learning process in which firms gradually upgrade their technological capabilities (Lee and Lim, 2001; Morrison et al., 2008) ${ }^{1}$ in close interaction with regional and national support structures (Evans, 1995; Lundvall et al., 2009; Wade, 2004). Two theoretical perspectives have been most influential in explaining how this upgrading process works. Capabilities may be upgraded either in a gradual learning process fueled by state-driven development initiatives and the integration of latecomer firms in global value chains and production networks (Gereffi, 1999; Morrison et al., 2008; Yeung and Coe, 2015), which we refer to from now on as catching-up, or in a branching process out of a region's pre-existing related technological capabilities (Hidalgo et al., 2007; Martin and Sunley, 2006; Neffke et al., 2014), which we refer to from now on as related diversification.

Both perspectives provide influential explanations on why and how new industries develop in non-core regions, but may be overly deterministic when assessing the potential of latecomers to develop radically new industrial paths. In general, both perspectives emerged from the analysis of processes of slow and gradual industrial upgrading, while more unlikely - but arguably important - 'jumps in the product space' (Hidalgo et al., 2007) or 'path-creating

\footnotetext{
${ }^{1}$ Technological capabilities are the "skills—-technical, managerial or organizational—-that firms need in order to utilize efficiently the hardware (equipment) and software (information) of technology, and to accomplish any process of technological change. Capabilities are firm-specific knowledge, made up of individual skills and experience accumulated over time” (Morrison et al., 2008: 41-42)
} 
catching-up’ processes (Lee and Lim, 2001) were left underexplored. This gap is particularly relevant as latecomer regions in emerging economies were recently identified as the places in which unrelated diversification is most pertinent (Pinheiro et al., 2018). In addition it seems particularly relevant for many recently emerging cleantech industries like wind power, solar power or electric mobility, which have been shown to develop in dynamic spatial trajectories that are strongly influenced by key actors from latecomer economies (Gosens and Lu, 2013; Quitzow, 2015; Sengers and Raven, 2015).

We argue that this gap of understanding stems from two shortcomings in existing theorizing. First, catching-up and diversification theories do not fully reflect the increasing influence of complex transnational linkages on industry formation dynamics. Cleantech is a case in point for industries that are not only influenced by regional path-dependencies and Western lead firms anymore, but increasingly by distributed networks of firm and non-firm actors in global innovation networks (Chaminade and Plechero, 2015; Coe and Bunnell, 2003), global (technological) innovation systems (Binz and Truffer, 2017; Quitzow, 2015; Wieczorek et al., 2015), global epistemic and professional communities (Coe and Bunnell, 2003; Wenger, 1998), or the interpersonal networks of transnational entrepreneurs (Drori et al., 2009; Saxenian, 2007; Yeung, 2009b). Second, especially related diversification theories tend to emphasize firm- and knowledge-based dimensions, while downplaying the role of non-firm actors, markets, policy making and institutional contexts in a broader systemic context (Binz et al., 2016b; Boschma et al., 2017; Dawley, 2014). To better capture the industry formation dynamics in a globalizing knowledge economy, a more systemic and internationalized perspective is thus needed.

This paper addresses these gaps by expanding on recent conceptual proposals from transitions and innovation studies that developed such systemic perspectives (Binz et al., 2012; Gosens et al., 2015; Huang et al., 2016; Quitzow, 2015; Wieczorek et al., 2015). In particular, it aims to specify the process behind unrelated diversification in the early industry formation phase. To that end, this paper explicitly adapts and applies a recent framework by Binz et al. (2016) to unrelated diversification in latecomer regions and describes the dynamic interrelationship between the generic 'absorptive capacity' of a latecomer region, the internationalized processes of the formation of system resources, and the processes anchoring international resources to domestic capabilities. Industry formation is conceptualized as a systemic innovation process, in which technology innovation, demand side dynamics, policy 
intervention, and shifts in user and investor preferences co-evolve (Bergek et al., 2008; Choi and Anadon, 2013; Dawley, 2014; Surana and Anadon, 2015; Tanner, 2014).

Our framework is validated with the case of the Chinese solar photovoltaics (PV) industry, which arguably represents an instance of unrelated diversification. A comprehensive literature review and expert interviews with 26 key stakeholders in the Chinese PV sector reveal that the PV industry formation process in China is not fully explained by conventional related diversification and catching-up theories, because: (a) Chinese companies mostly operated outside the global value chains of Western and Japanese PV lead firms; (b) capabilities in closely-related sectors emerged only after the PV industry took root in China; and (c) the central government initially did not support this particular industry with a traditional exportoriented developmental state-type policy approach, as opposed to other high-tech industries. We rather find successful industry formation to be the outcome of a complex international entrepreneurial process in which Chinese pioneers directly mobilized system resources from various places around the world and successfully combined them with (initially unrelated) generic absorptive capacity, like mass-production capabilities available in the Yangtze River delta region.

This argument is elaborated in the following structure. Section 2 summarizes existing explanations of industry formation and identifies gaps in their theorizing of unrelated diversification processes. We then formulate an analytical framework that specifies the main characteristics of the generic absorptive capacity of a latecomer region and four key system resources for early industry formation. We subsequently discuss how the four system resources and the generic absorptive capacity might be connected through processes and actors working across and between regional and national borders. Section 3 justifies the empirical case and describes the methodological approach. In section 5, we apply our framework to solar PV manufacturing in China, illustrating the need to further explore the role of unrelated diversification processes in the catching up strategies of latecomer countries. Sections 5 and 6 discuss the generalizability of our framework, summarize our contributions to transitions and innovation studies, and derive lessons for policymaking.

\section{Towards an analytical framework for unrelated diversification}

In the remainder, we will first critically review the most influential theories on industrial path creation from the catching-up and related diversification literatures and then discuss the 
contours of an updated analytical framework for unrelated diversification in latecomer contexts.

\subsection{Existing models of industry formation in latecomer regions}

To date, the catching-up literature has analyzed in most depth how latecomer regions create and absorb knowledge to upgrade their technological capabilities and industrial structure (Evans, 1995; Fu et al., 2011; Gereffi, 1999; Lee and Lim, 2001). Initial debates focused on whether States can actively push industrialization by strategically creating infant industries (Lall, 1992; Wade, 1988). Related state-led development strategies were initially discussed under the label of “import-substituting industrialization” (Hirschman, 1968). This first generic model was gradually replaced by the Asian model of export-oriented industrialization, which combined home market protection with export promotion (i.e. through low-interest financing, infrastructure investment, active trade facilitation), the picking of winners and discipline imposed by the need to demonstrate export-success (Amsden, 1992; Wade, 2004). More recently, the notion of industrial upgrading in global value/production chains took center stage (Morrison et al., 2008; Yeung, 2009a). Under this account, firms in latecomer countries may acquire new capabilities through integration in the supply networks of global lead firms (e.g., General Motors in the car sector or Apple in the ICT industry) and by adapting regional institutional structures to the strategic needs of leading international actors (Coe and Yeung, 2015; MacKinnon, 2012). Finally, China arguably developed a specific variant of catchingup, which combines several elements mentioned above with trading market access for foreign firms for (non-conventional forms of) knowledge transfer (Altenburg et al., 2008; Lema and Lema, 2012; Liu and Dicken, 2006; Xielin, 2005).

In general, in catching-up models, latecomer firms are expected to catch up with Western lead firms either in a gradual local learning process and/or through integration in the supply networks of global lead firms. In that process, firms in latecomer countries usually start in a basic supplier role (original equipment manufacturing, OEM) and subsequently move to more knowledge intensive manufacturing and management processes, ultimately including original brand design (Gereffi, 1999; Malerba and Nelson, 2011). Latecomer firms may also directly partner with leading firms through licensing or joint ventures and over time develop more advanced technological capabilities and management routines (Lee and Lim, 2001; Lewis, 2011). In both cases, learning and upgrading happen through consecutive rounds of in-house $\mathrm{R} \& \mathrm{D}$ and reverse engineering, as well as interaction with regional knowledge infrastructure, 
policy makers and other intermediary actors that steer emerging industries with a ‘developmental state’ approach (Evans, 1995; Wade, 2004; Yeung and Coe, 2015).

The empirical relevance of these catching-up models has been extensively validated with historical case studies from latecomer countries in Asia, South America and Africa (Fu et al., 2011; Gereffi et al., 2005; Malerba and Nelson, 2011). Among others, examples from Taiwanese PC manufacturing, the apparel industry in several East Asian countries (Gereffi, 1999), or the automobile, consumer electronics, and mobile phone industries in South Korea (Lee and Lim, 2001), all showed that targeted State interventions and the integration of latecomer firms in global value chains was of key importance in their learning and industrial upgrading process. Similar processes were relevant for catching-up in cleantech sectors like wind power (Lewis, 2011; Surana and Anadon, 2015) or the electric car industry (Schmidt and Huenteler, 2016).

Related diversification theory contrasts catching-up theories with a stronger emphasis on the endogenous pre-conditions of industrial development. It argues that regions tend to diversify into industries that are closely related to existing knowledge bases and capability portfolios (Frenken and Boschma, 2007; Hidalgo et al., 2007; Neffke et al., 2011). New industries develop in a localized spillover process in which the organizational routines and manufacturing competence of existing firms are recombined to form a new industrial path that deviates from previous trajectories (Frenken and Boschma, 2007). Regional spin-offs, spinouts and territorially embedded knowledge recombination play a key role in this process (for an overview see Simmie, 2013). Firms in latecomer regions that either lack capabilities that could be creatively recombined (Frenken and Boschma, 2007), or have capabilities only in low-tech products which cannot be used to directly move to more complex product categories (Hidalgo et al., 2007), have low chances for diversifying into new activities. Empirical studies in European, US and Asian regions have proven that the regional industrial composition evolves in an incremental branching process, called 'related diversification' (Boschma et al., 2012; He et al., 2016; Neffke et al., 2011).

While this literature has convincingly proven the pertinence of incremental economic evolution, it only recently embraced the question why regions in some cases still manage to branch into new industries that are not directly related to pre-existing regional capabilities (Boschma et al., 2017; Pinheiro et al., 2018; Zhu et al., 2017). This shortcoming is significant, 
since for latecomer regions, it is often "precisely the long jumps [to more unrelated industries] that generate subsequent structural transformation, convergence and growth” (Hidalgo et al., 2007: 487).

In summary, while both approaches have strong merits in explaining industrial path creation as a process of gradual learning and diversification, two main gaps stand out in their understanding of contemporary industry formation processes. First, even though the literature has moved from a principal focus on intra-firm routines and technological capabilities to an increasing integration of the influence of non-firm actors like the State, investors, interest groups or industry associations (Dawley, 2014; Jung and Lee, 2010; Simmie, 2013; Tanner, 2014), we still have a rather limited understanding of the systemic process that enables firms in latecomer regions to 'jump’ into novel activities that are unrelated to their previous specialization, in particular in policy-driven industries like cleantech. Second and related, the role of international actor networks and extra-regional linkages beyond multinational corporations (MNCs) and well-structured global value chains (GVC) or production networks (GPN) is not well described or conceptualized (Binz et al., 2016b; Coenen et al., 2012). The existing theories provide detailed explanations for capability upgrading in well-established sectors in which global value chains have developed in the past, but they are less directly relevant for understanding industry formation in dynamically emerging (cleantech) sectors, where value chains are more fluid, markets depend strongly on policy interventions, and key inputs to the innovation process are spread in loosely structured international actor networks.

\subsection{Connecting catching-up and diversification theories with innovation studies}

To better understand the early industry formation process, various authors recently proposed relating the industrial path creation literature more closely to concepts from the transitions literature and, in particular, to the technological innovation systems (TIS) concept (Binz et al., 2016b; Boschma et al., 2017; Gosens et al., 2015; Quitzow, 2015). TIS are defined as “a network of agents interacting in a specific economic/industrial area under a particular institutional infrastructure or set of infrastructures and involved in the generation, diffusion, and utilization of technology” (Carlsson and Stankiewicz, 1991, p. 111). TIS research focused on how these networks of agents support new industries by inducing seven key systembuilding activities (or 'functions') related to knowledge creation, entrepreneurial experimentation, guidance of the search, market formation, resource mobilization, creation of 
legitimacy and the creation of positive externalities (Bergek et al., 2008; Hekkert et al., 2007). In this view, firm-based knowledge constitutes a key resource for early industry formation, which is interconnected with other important innovation processes related to demand side dynamics (market formation), financial investment (resource mobilization) and the embedding of new technologies in existing institutional structures (legitimation).

While the functional approach to TIS was successfully applied to study innovation dynamics in Western cleantech sectors, it showed various limitations in the context of emerging economies (Gosens et al., 2015; Quitzow, 2015; Wieczorek et al., 2015). Some scholars pointed out that functional TIS analysis needed to explicitly incorporate transnational linkages and interdependencies between subsystems of the same industry in different parts of the world (Gosens et al., 2015; Quitzow, 2015; Wieczorek et al., 2015). Others criticized the functional approach for providing rather fuzzy and broad policy advice, because, for example, the application of the analysis makes it difficult to consistently assign policy instruments to each of the seven system functions (Bening et al., 2015). One key limitation of the TIS-based studies appears to be their treatment of spatial boundaries (Coenen et al., 2012). In traditional TIS studies, industry formation is conflated with system building at national and regional levels (even when various ‘transnational linkages’ are highlighted), so the concrete connection between the system functions and industry formation remain elusive at best.

To avoid this conceptual confusion, Binz et al. (2016b) distinguished four types of system resources that are instrumental to any early industry formation process: knowledge, market access, financial investment and technology legitimacy. The basic rationale of this approach is aligned with evolutionary economic geography and the catching-up literature in arguing that firms depend on organizational resources (tangible and intangible assets like financial assets, know-how, routines, etc.) for their commercial development (Morrison et al., 2008; Peteraf, 2005). In addition, and particularly in newly emerging industries, strategic resources also emerge from inter-firm networks or at the level of a wider innovation system (Musiolik and Markard, 2011; Musiolik et al., 2012). We thus differentiate between two generic types of firm-external assets: 'generic regional assets' (see Maskell and Malmberg, 1999) (in the remainder labeled 'generic absorptive capacity') and industry-specific 'system resources'. The latter are specific to the industry in focus and may develop locally, but also in multiscalar networks that transcend regional and national borders (Binz et al., 2016b; Binz and Truffer, 2017). Generic absorptive capacity, in contrast, may be relevant for various industries 
at the same time, while always being embedded in concrete territorial contexts (Maskell and Malmberg, 1999).

\section{Generic absorptive capacity in latecomer contexts}

In terms of generic absorptive capacity, the diversification and catching-up literatures both argue that a place's pre-existing material assets and infrastructure, human assets like labor skills and knowledge, technological capabilities and firm routines, as well as institutional configurations influence the potential for industries being formed. In their sum, these assets denote the historically grown 'absorptive capacity’ of the economic system in a given place, which was a concept originally developed at the firm level and defined as "the firm's ability to identify, assimilate, and exploit knowledge from the environment” (Cohen and Levinthal, 1989). Catching up models rely on the concept of absorptive capacity adapted to the national level to reflect the fact that national (or regional) absorptive capacity cannot be merely understood as the aggregation of the absorptive capabilities of individual firms or industries and must account for the institutions and governance arrangements shaping their collective performance (Evans, 1995; Narula, 2004; Wade, 2004). Dahlman and Nelson (1995) defined national absorptive capacity as the "ability to learn and implement the technologies and associated practices of already developed countries.”

In the remainder, we distinguish a region's (or a nation's) generic absorptive capacity from its industry-specific resource formation processes (cf. Table 1), in order to disentangle the determinants of industrial path creation that cut across many industries and factors that are specific to a particular industry. The factors determining the generic absorptive capacity of a region include: (1) its basic infrastructure and macro-economic environment, (2) its technological capabilities and knowledge exploitation system, as well as (3) its institutional configuration and domestic policy interventions that support e.g. knowledge accumulation, technology transfer and venture capital mobilization (Lema and Lema, 2012; Rock et al., 2009; Sauter and Watson, 2008). Material infrastructure (roads, electricity, freshwater supply, etc.), generic technological capabilities (basic know-how and know-what), as well as a conducive institutional infrastructure (legal systems and macro-political environments) are key prerequisites for any industrial activity to emerge. Yet, taken alone, they can hardly 
explain why a certain industry locates in a place or not. To understand this, a structured view on the industry-specific system resource formation is needed. ${ }^{2}$

Table 1: Generic absorptive capacity for industry formation

\begin{tabular}{lll}
\hline Dimensions & Streams of literature & Key references \\
\hline $\begin{array}{l}\text { Material } \\
\text { infrastructure }\end{array}$ & Development economics & $\begin{array}{l}\text { (Perkins, 2003; Sauter and } \\
\text { Watson, 2008) }\end{array}$ \\
$\begin{array}{l}\text { Technological } \\
\text { capabilities }\end{array}$ & $\begin{array}{l}\text { Catching-up literature, } \\
\text { Economic geography }\end{array}$ & $\begin{array}{l}\text { (Hidalgo et al., 2007; Lee and } \\
\text { Lim, 2001; Morrison et al., 2008) }\end{array}$ \\
$\begin{array}{l}\text { Comparative } \\
\text { institutional } \\
\text { advantage }\end{array}$ & $\begin{array}{l}\text { Institutional sociology, } \\
\text { Development economics } \\
\text { Economic geography }\end{array}$ & $\begin{array}{l}\text { (Acemoglu and Robinson, 2012; } \\
\text { Coenen et al., 2012; Hall and } \\
\text { Soskice, 2001; Wade, 2004) } \\
\text { (Nelson, 1993; Wade, 2004) }\end{array}$ \\
\hline
\end{tabular}

\section{Industry-specific system resources}

Table 2 further specifies the four industry-specific system resources developed by Binz et al. (2016), which are seen as the necessary conditions for industrial path creation. In other words, if access to one resource is missing, entrepreneurs will have to surmount the challenge of creating or obtaining it (assuming it is available elsewhere). As they are the emergent outcome of collective action, they cannot be mobilized and controlled by isolated organizations, but rather emerge from the interaction in heterogeneous actor networks (Bathelt and Glückler, 2005; Musiolik et al., 2012). This is again particularly relevant for cleantech industries where government regulation and, in some cases, additional support policies, have been shown to play an instrumental role in supporting industry formation (Mazzucato, 2015).

\footnotetext{
${ }^{2}$ Note that generic forms of knowledge, investment, market structures and legitimacy may initially be part of a latecomer country's generic absorptive capacity, which may then be turned into industry specific resources in a collective system building process.
} 
Table 2: Key system resources for industry formation

\begin{tabular}{|c|c|c|c|c|}
\hline Resource & Sub-dimensions & $\begin{array}{l}\text { Streams of } \\
\text { literature }\end{array}$ & Key references & Basic argumentation \\
\hline Knowledge & $\begin{array}{l}\text { Codified knowledge } \\
\text { (Know-what) } \\
\text { Tacit knowledge } \\
\text { (Know-how) }\end{array}$ & $\begin{array}{l}\text { Economic } \\
\text { Geography } \\
\text { Innovation } \\
\text { studies }\end{array}$ & $\begin{array}{l}\text { (Asheim and Coenen, 2005; } \\
\text { Bathelt and Glückler, 2005; } \\
\text { Crevoisier and Jeannerat, } \\
\text { 2009; Freeman, 1987; } \\
\text { OECD, 1996) }\end{array}$ & $\begin{array}{l}\text { In a knowledge-based globalizing } \\
\text { economy, knowledge (codified } \\
\text { and tacit) is a key resource for } \\
\text { any innovative activity. }\end{array}$ \\
\hline Markets & Commodification & $\begin{array}{l}\text { Social } \\
\text { construction of } \\
\text { markets } \\
\text { Transition } \\
\text { studies }\end{array}$ & $\begin{array}{l}\text { (Dewald and Truffer, 2012; } \\
\text { Fligstein and Zhang, 2011) }\end{array}$ & $\begin{array}{l}\text { In newly emerging industries, } \\
\text { commoditized products and } \\
\text { protected niche markets are not } \\
\text { given, but actively created by } \\
\text { early entrepreneurs, user groups, } \\
\text { and/or government intervention }\end{array}$ \\
\hline $\begin{array}{l}\text { Financial } \\
\text { investment }\end{array}$ & $\begin{array}{l}\text { Venture capital, } \\
\text { banks, equity and } \\
\text { institutional investors } \\
\text { Government } \\
\text { subsidies }\end{array}$ & $\begin{array}{l}\text { Management, } \\
\text { entrepreneurship } \\
\text { and business } \\
\text { literature }\end{array}$ & $\begin{array}{l}\text { (Gustafsson et al., 2016; } \\
\text { Surana and Anadon, 2015; } \\
\text { Teppo, 2006; van den } \\
\text { Bergh, 2013) }\end{array}$ & $\begin{array}{l}\text { Entrepreneurial actors in a } \\
\text { latecomer region need to mobilize } \\
\text { various forms of financial } \\
\text { investments to keep their new } \\
\text { ventures in business and growing. }\end{array}$ \\
\hline $\begin{array}{l}\text { Technology } \\
\text { Legitimacy }\end{array}$ & $\begin{array}{l}\text { Technology } \\
\text { certification, } \\
\text { standards }\end{array}$ & $\begin{array}{l}\text { Institutional } \\
\text { Sociology }\end{array}$ & $\begin{array}{l}\text { (Johnson et al., 2006; } \\
\text { Suchman, 1995; Zelditch, } \\
\text { 2001) } \\
\text { (Aldrich and Fiol, 1994; } \\
\text { Rao, 2004) }\end{array}$ & $\begin{array}{l}\text { New technologies that have no } \\
\text { precedent in the social order are } \\
\text { confronted with high skepticism } \\
\text { by users, investors, and policy } \\
\text { makers. They thus have to be } \\
\text { aligned with the relevant } \\
\text { (normative, regulative and } \\
\text { cognitive) institutional structures }\end{array}$ \\
\hline
\end{tabular}

In theory, all four system resources may emerge inside one single country or even a single region. Yet, especially in new industries and the context of latecomer countries, they are often lacking or not well adapted to an industries' needs (Gosens et al., 2015). Local firms lack specialized knowledge, the education system does not reach international standards, and cooperation between various stakeholder groups are unstructured, thus hampering the build-up of collective innovation strategies (Chaminade and Plechero, 2015; Freeman, 1987; Nelson, 1993). Also, financial expertise on how to support newly emerging industries that sell products with unclear performance characteristics will likely be missing. Latecomer firms aiming at fast catching-up will thus in many cases have to mobilize system resources that have developed elsewhere.

Recent research shows that - at least in some industry types - system resources that have emerged in one place, may become accessible to the other actors in the same (global) innovation system (Binz and Truffer, 2017; Quitzow, 2015). For example, once a group of companies, government agencies and end-user organizations has constructed a new market segment in one place, it may be served also by extra-regional firms and new entrants in the same industry 
(Dewald and Truffer, 2011; Musiolik et al., 2012). A quality standard from one place can equally inform innovation efforts in other regions, a financing tool developed in a specific country might be used to reap investment opportunities in foreign countries and even policy instruments to support a nascent industry may diffuse to various places around the world through indirect spillovers (Gosens et al., 2015; Quitzow, 2015; Sengers and Raven, 2015). To understand the wide range of mechanisms that support industry formation processes, one thus needs to analyze how and where system resources emerge, and how they can get accessed and anchored to the 'generic absorptive capacity' in latecomer regions.

\subsection{Analytical framework: Anchoring extra-regional system resources to latecomer region's generic absorptive capacity}

Figure 1 summarizes the model of unrelated diversification outlined above. System resources develop in complex spatial configurations that often span several regions and countries of the same global innovation system (Binz and Truffer, 2017). For example, resource 3 in Figure 1, (e.g. a 'niche market') might emerge from one specific country that implements a market deployment subsidy. Resource 1 in Figure 1, (e.g. 'knowledge') might in turn emerge from an R\&D network spanning more than one region inside the same country (Regions A and B in Country 2). Finally, resource 2 (e.g. 'financial investment') might get mobilized in several regions at the same time and diffuse to a latecomer context through the activities of venture capital firms and investment banks with specialized industry expertise. Figure 1 is meant to illustrate that a latecomer country with generic absorptive capacity may embark on a 'long jump in the product space' if it is able to access industry-specific system resources developing elsewhere and anchor them to the locally available generic absorptive capacity. This stands in contrast to conventional TIS and catching-up approaches, which assume that latecomer regions need to develop a full-fledged local innovation system for developing a competitive industry. 
Figure 1: Anchoring extra-regional resources in early industry formation - conceptual model

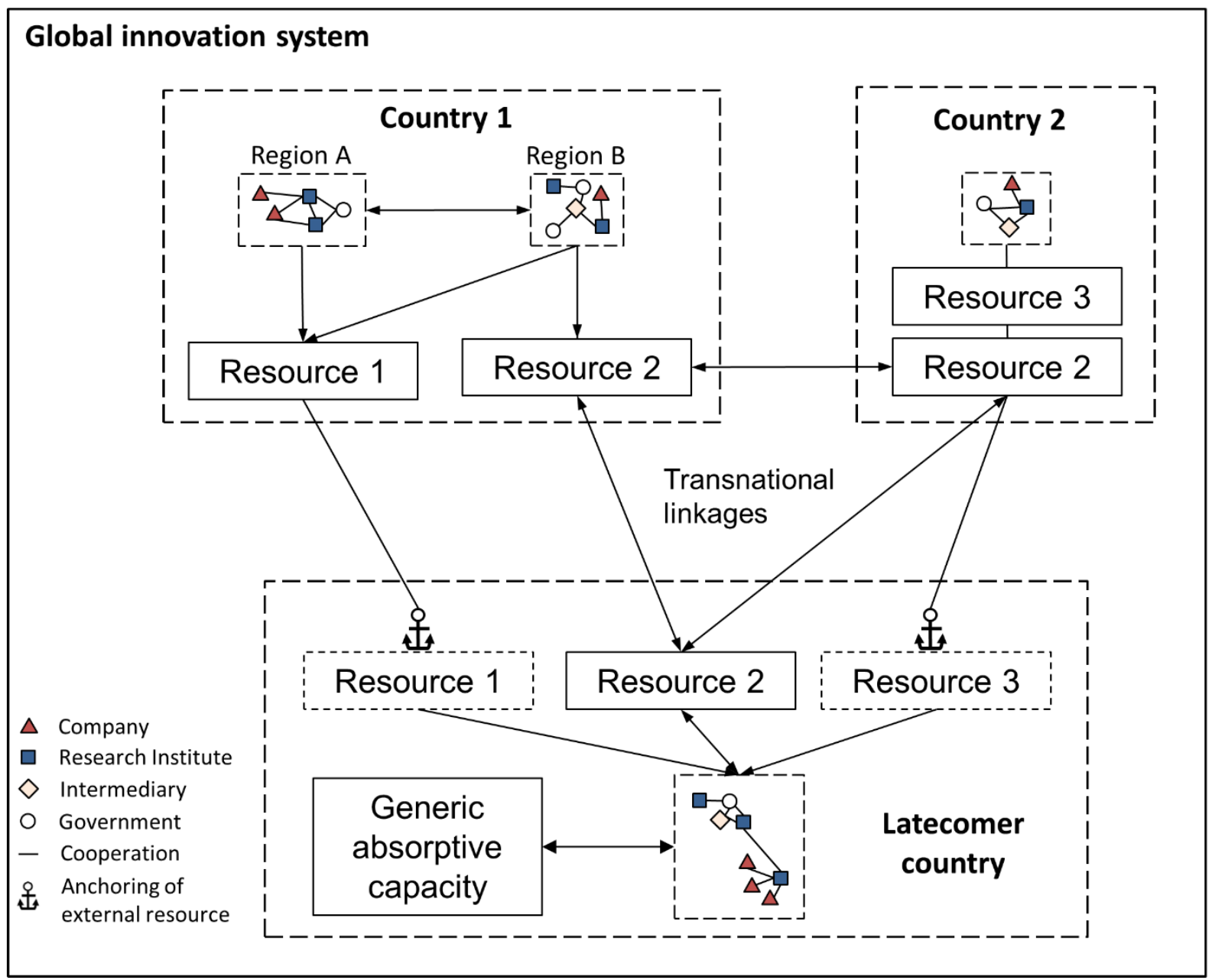

The mobilization and anchoring of system resources requires actors moving between regional subsystems. Actors able to integrate activities in different parts of a global innovation system (GIS) are, among others, transnational entrepreneurs, traveling industry experts, or highprofile technology advocates (Drori et al., 2009; Sengers and Raven, 2015). They move from one place to the next, studying and working in different regional contexts, eventually returning to their home-regions and founding new ventures (Drori et al., 2009; Saxenian, 2007; Yeung, 2009b). By moving between different regional subsystems they build up social capital that puts them in a favorable position to act as system builders in latecomer regions (Drori et al., 2009; Saxenian, 2007). Being embedded in and accumulating experiences in several subsystems of the GIS allows them to perceive the global state of resource formation and to identify windows of opportunity that are invisible to exclusively regionally embedded actors (Drori et al., 2009; Saxenian, 2007; Yeung, 2009b). 
When re-contextualizing their knowledge about global system structures, they can use extraregional system resources to upgrade a latecomer context's generic absorptive capacity. This 'anchoring' process in our understanding may make latecomer firms internationally competitive over a relatively short period of time. Some even argue that 'born global' companies that master this globalized resource transplantation process have become the spearheads of today's knowledge economy (Mathews, 2006). Or, as Crevoisier and Jeannerat (2009, 1231) put it, "the most competitive enterprises are today those that take the most rapid decisions regarding how they will act globally and that combine various types of knowledge that exist elsewhere. It is no longer a question of simply going out to find the appropriate competencies where they are the least expensive, but one of imagining new projects based on competencies that are currently accessible.” To substantiate these arguments and illustrate our framework, we will now apply it to our empirical case, the formation of the crystalline solar PV module industry in China.

\section{Case selection and methods}

\subsection{Case selection}

The solar PV sector in China was chosen as an illustrative case of an unrelated diversification process, which has created extensive debates in academic and policy circles (Fischer, 2012; Huang et al., 2016; Iizuka, 2015; Nahm, 2014; Quitzow, 2015; Zhang and Gallagher, 2016; Zhang and White, 2016). This case nicely matches our analytical ambitions, as it challenges some key tenets of catching-up and industrial relatedness literatures. First, domestic technological capabilities in related industries were limited when the Chinese PV industry started growing quickly around 2000 (Energy Research Institute, 2000; Zhao et al., 2013). A small PV sector had been established in China in the late 1960s for the national space program, as well as for rural electrification projects, e.g. in Tibet (Energy Research Institute, 2000; Zhao et al., 2013). Yet, by the late 1990s, only 17 PV module companies and 16 suppliers were active in China, all of which were small state-owned enterprises, except for one - ultimately unsuccessful - US-Chinese joint venture (Energy Research Institute, 2000; Zhang and White, 2016). By 1998, the local industry’s production capacity stood below 2.3 MW per year (compared to 277 MW globally) and companies were struggling with considerable quality problems (Cabraal, 2004; Energy Research Institute, 2000; Varadi, 2014; Yang et al., 2003). In 2000, a major synthesis report by the NDRCs Energy Research Institute drew a discouraging picture of the Chinese PV industry, highlighting pertinent problems like 
“small production scale, low technology level, out-of-date auxiliary equipment” (Energy Research Institute, 2000, 12).

Second, foreign direct investment was also absent during most of the 1990s and 2000s and none of the Western lead firms were involved in outsourcing R\&D or production to China (Zhang and White, 2016). Branching processes from the most closely related sectors — such as semi-conductors manufacturing and (poly-) silicon production (see Bruce, 2007) — initially also played a rather limited role. In the early 2000s, China's semi-conductor industry was state-owned, global market shares of Chinese manufacturers stood below $2 \%$ and foreign semiconductor MNCs were yet to establish manufacturing contractors in China (Choi and Anadon, 2013; de la Tour et al., 2011; SIA, 2014; Yu et al., 2016). The main spillover to the Chinese PV industry appear to be semiconductor engineers from Taiwan (which had 3\% of market share in semiconductor manufacturing in 2000) that were hired by Chinese PV startups (SIA, 2014; Yu et al., 2016). In the technologically also closely related polysilicon industry, China developed its own technological capabilities only in the mid-2000s, forcing the pioneering Chinese PV manufacturers to import about 95\% of their silicon supplies from abroad until 2008 (Fischer, 2012; Li, 2009).

Finally, the industry formation trajectory in solar PV also contradicts several well-established catching-up models. I.e. it neither represents a classic case of export-oriented industrialization with an initial, protected home market, nor a typical case of Chinese catching-up involving some form of technology transfer in return for market access. In fact, the Chinese central government took a critical stance against the development of a Chinese solar PV industry during most of the early 2000s (Quitzow, 2015; Zhang and He, 2013; Zhang et al., 2014; Zhao et al., 2013). Given the bad experiences from PV-powered rural electrification campaigns, some government experts even argued that there was no comparative advantage for Chinese manufacturers in competing with the well-established PV manufacturers in Japan, the USA and Europe (Energy Research Institute, 2000; Zhang and White, 2016). In summary, around 2000, nobody - including China's central government which was actively supporting other cleantech industries such as wind power - was expecting China to become a global powerhouse in PV manufacturing over less than a decade. This notwithstanding, between 2000 and 2010 China went from a 1\% share in PV module production to shipping more than half of global PV panel output (Figure 2). Overall, given the lack of integration into global value chains and China's initial low level of capabilities in directly related sectors, this case 
promised unique insights into a latecomer country’s 'jump in the product space' (Hidalgo et al., 2007).

Figure 2: Total global PV panel production (top panel) and global distribution of PV panel manufacturing capacity (bottom panel)

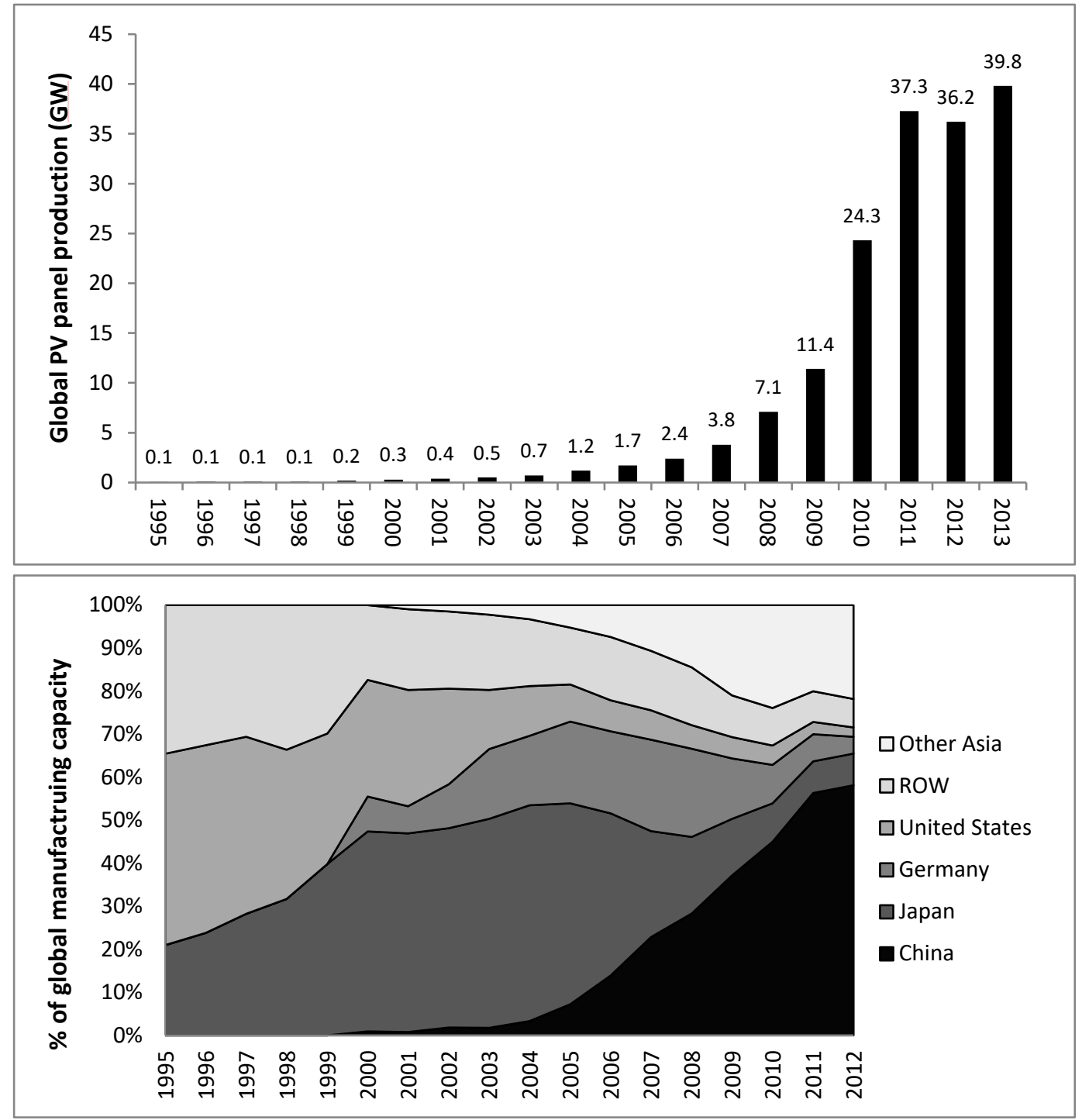

Source: Own design, based on data from Earth Policy Institute (2013), also see (Nahm and Steinfeld, 2014; Binz et al. 2017b)

\subsection{Methods}

An in-depth qualitative case study design (Yin, 2012) based on our analytical framework was used to reconstruct the early industry formation process in China. First, the emergence and accessibility of system resources in the GIS was analyzed based on a review of extensive secondary literature on the PV sector's global evolution (cf. section 4). Second, the resource mobilization strategies of the pioneering Chinese entrepreneurs were assessed with an in- 
depth interview campaign in China. In contrast to prior studies that covered generic system building activities (Huang et al., 2016; Iizuka, 2015; Quitzow, 2015), our empirical campaign explicitly focused on mobile technology experts and their agency in connecting domestic and global resource formation processes. In total, 26 semi-structured interviews were conducted with the founders, CEOs, CTOs and senior managers of the pioneering Chinese PV companies, as well as with other key experts from China and abroad that were involved in the early development phase of the solar PV industry in China (see Appendix 1). Interviews were conducted during a two-month fieldwork campaign and lasted between 45 minutes and two hours. All interviews were recorded, transcribed verbatim and codified according to our system resources framework. Codified interview excerpts were analyzed with qualitative content analysis (Strauss and Corbin, 1998) in MAXQDA software to identify the strategies used to anchor external system resources to China's generic absorptive capacity. To avoid interpretation biases and post-hoc rationalization, the information from interviews was extensively triangulated with secondary data and PV companies’ annual reports.

\section{The emergence of the Chinese solar PV industry}

In this section, we will first summarize the early history of the Chinese PV industry and then assess the country's initial absorptive capacity. We then turn to analyzing the global evolution of each system resource and the way it either emerged in China or was anchored from outside.

\subsection{History of the Chinese solar PV sector}

Until the late 1990s, the Chinese PV sector was progressing slowly and prone with quality problems. This situation changed around 2000, when four new PV panel manufacturers (Suntech, Trina, Yingli, and Canadian Solar ${ }^{3}$ ) were founded that pioneered a new development trajectory (cf. table 3).

\footnotetext{
${ }^{3}$ Canadian Solar is a Canadian company, which was founded by an ethnic Chinese. While its headquarters are in Canada, it outsourced considerable parts of its PV panel production to China starting in 2003.
} 
Table 3: Major PV panel manufacturers in China, 2014

\begin{tabular}{lcccccc}
\hline Name & Foundation & IPO & Bankruptcy & Headquarters & $\begin{array}{l}\text { Revenue } \\
\text { (bn. US\$, 2014) }\end{array}$ & $\begin{array}{c}\text { Shipments } \\
\text { (MW, 2014) }\end{array}$ \\
\hline Yingli Solar & 1997 & 2006 & n.a. & Baoding & 2.08 & 3’361 \\
Trina Solar & 1998 & 2006 & n.a. & Changzhou & 2.29 & 3’660 \\
Canadian Solar & 2001 & 2006 & n.a. & Ontario CA & 2.96 & 3’105 \\
Suntech & 2001 & 2005 & 2012 & Wuxi & n.a & n.a. \\
Sunergy & 2004 & 2007 & n.a. & Tianjin & 0.36 & 577 \\
LDK Solar & 2005 & 2007 & 2014 & Jiangxi & n.a. & n.a. \\
JA Solar & 2005 & 2007 & n.a. & Shanghai & 1.82 & 3’057 \\
Jinko Solar & 2006 & 2010 & n.a. & Shanghai & 1.61 & 2'943 \\
\hline
\end{tabular}

Source: Company annual reports 2014

By the mid-2000s, these pioneering companies had all turned into privately owned ventures with dominant global market shares. Their success motivated investors and other entrepreneurs to move into the solar PV industry, which initiated a second wave of startups (comprising companies like Jinko Solar, Sunergy, LDK, or JA Solar) and a domestic investment boom from 2004 (Quitzow, 2015). The boom abruptly halted in 2008 when the global financial crisis led to a meltdown of subsidized PV markets overseas. After 2008, the Chinese government initiated domestic market deployment policies, included solar PV in its list of strategic industries, and Chinese development banks issued large loans to the tumbling companies (Dong et al., 2014; Fischer, 2012). The industry increasingly consolidated; some major companies from the first and second startup waves developed into vertically integrated lead firms in the global value chain for crystalline solar PV products, while others crumbled under their excessive debt levels and the introduction of anti-dumping tariffs on Chinese solar PV panels in the US and the EU (Curran, 2015; Quitzow, 2015). 
Figure 3: Development phases in China's solar PV manufacturing industry

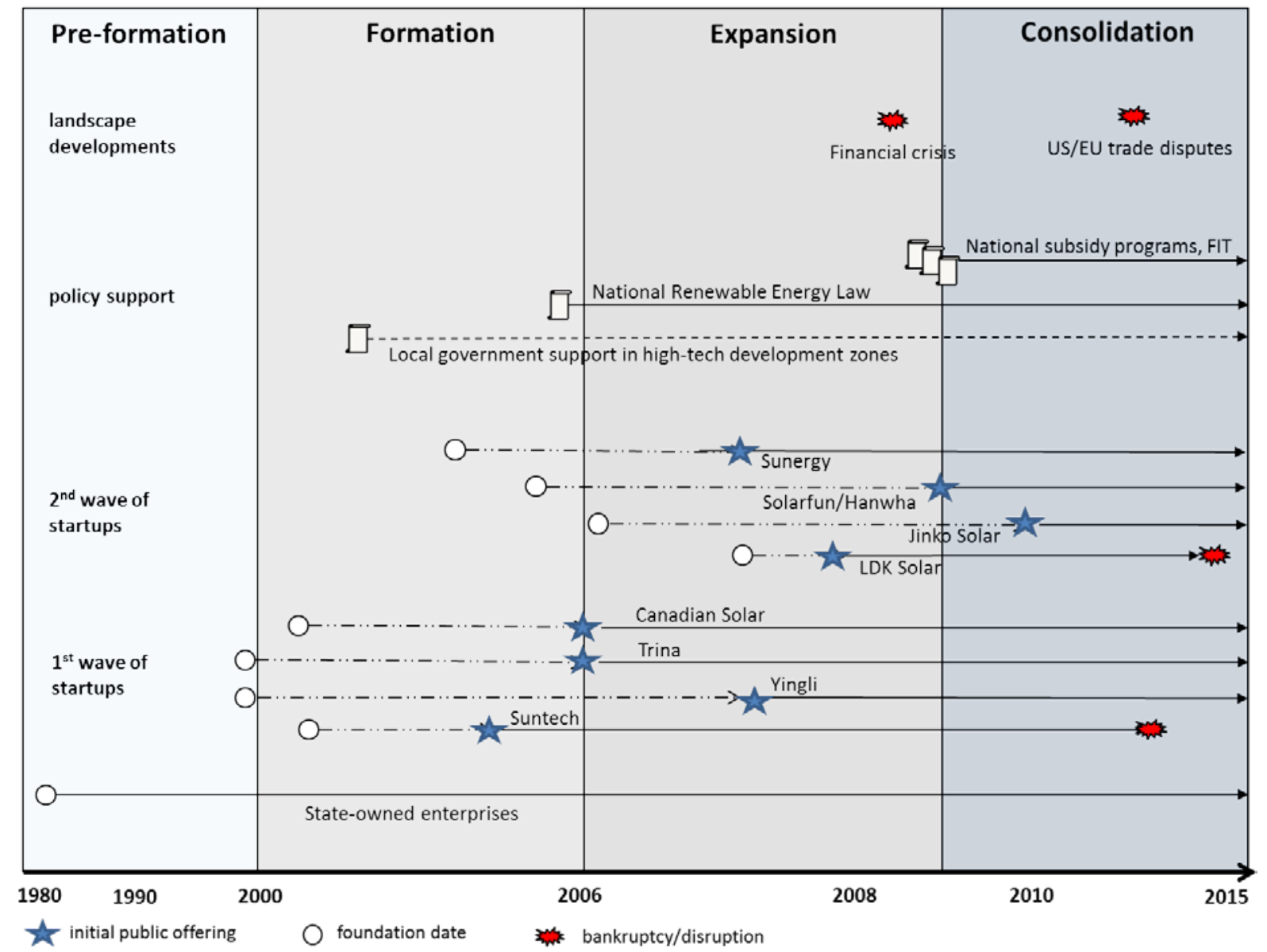

Industry formation in China (cf. Figure 3) can thus roughly be differentiated into a preformation, formation, expansion and consolidation phase. As our analytical framework emphasizes early industry formation dynamics, the subsequent analysis will mostly focus on the (pre-) formation and early expansion phases shown in Figure 3, spanning from the late 1990ies until about 2008.

\subsection{Generic absorptive capacity in China}

The first step in our analytical framework is assessing China's initial generic absorptive capacity (cf. table 1). In terms of basic material infrastructure, China provided favorable initial conditions. Access to world-class trade infrastructure in the Shanghai and Tianjin region was of key importance for developing an export-based industry in the early phase (Interviews 1, 2, 13, 16). Several generic technological capabilities were also available; China had a relatively well-developed education system that provided the new industry with university graduates with solid engineering education (see section 4.2). In addition, 
throughout the 1980s and 1990s, China had built-up industry clusters specialized in manufacturing exportable consumer goods (toys, furniture, etc.). Companies in these clusters had built strong competencies in identifying and absorbing outside technologies to quickly scale-up mass manufacturing. In their analysis of the wind turbine and solar PV sectors in China, Nahm and Steinfeld (2014) emphasized "how quickly products can be developed and brought to market” as perhaps the most important feature of Chinese innovation in manufacturing. Indeed, several pioneering PV companies emerged from existing businesses with experience in unrelated industries with such generic capabilities: Yingli was founded by a serial entrepreneur with experience in agricultural technology and water treatment products; Trina Solar by a Chinese entrepreneur in the detergent business, LDK solar by the director of a firm in protective glove manufacturing (Zhang and White, 2016).

In terms of comparative institutional advantage, China provided general macro-political stability, while the rule of law and intellectual property rights were not always rigorously enforced. ${ }^{4}$ A key comparative institutional advantage was the entrepreneurial culture in the Yangtze River Delta region (Witt, 2014), as well as a national policy strategy to support export-oriented industries in dedicated high-tech zones. Several interviewees pointed to the important role of pro-active, entrepreneurial local governments (Interviews 3, 13, 20, 24) that channeled funds from these high-tech programs to newly established PV ventures (Interviews 9, 11, 23). In addition, China's lax enforcement of environmental policies allowed for the fast upscaling of manufacturing facilities, without thorough environmental impact assessments (Interviews 10, 18). In China, new PV manufacturing plants could be built in a matter of months (Interviews 9, 10,14), while the same process took foreign competitors up to three years (Nahm and Steinfeld, 2014; Zhang and White, 2016).

In sum, in the early 2000s, the Chinese context provided abundant generic absorptive capacity, but relatively limited technological capabilities and system resources that were directly related to the solar PV industry's needs. The pioneering entrepreneurs accordingly justified their decision to start new PV ventures in China not with a supportive pre-existing resource base, but rather with the generic support by local governments and a certain home bias:

\footnotetext{
${ }^{4}$ In our interviews, IPR issues were never mentioned as a hindering or supporting factor for Chinese catching-up and to our knowledge, industry formation in China happened without major disputes on IPR infringement.
} 
"To be honest I could have started the company anywhere in the world - like Australia, US, or Europe. But the reason I choose China is because [...] when I started a new business, I did not have much experience doing business overseas - you have to deal with laws and so on. So I thought China is my motherland. Same language, lots of support from local investors and the local government."[founder of a Chinese PV company]

This move into largely uncharted terrain meant that in the early years, pioneering Chinese PV firms had to invest heavily in creating a supportive, localized system resource base (Zhang and White, 2016). To understand this process in more detail, we will now turn to assessing the four industry-specific system resources of our analytical framework. For each resource, we will first characterize its development in the global innovation system and turn to analyzing how Chinese actors accessed it and used it to transform domestic generic absorptive capacity into industry-specific system resources.

\subsection{Industry-specific system resources}

\subsubsection{Knowledge}

Knowledge creation in the GIS

Solar PV modules are a highly standardized mid-tech commodity with a knowledge base in material sciences, electric engineering, metallurgy, and semi-conductor technology (Huenteler et al., 2016). PV-related knowledge is relatively easily codifiable and accessible in publications, patents and technical guidelines (de la Tour et al., 2011; Zheng and Kammen, 2014). Technology expertise in the PV field was accordingly from the early beginning on relatively footloose and circulating between the USA, Europe and Japan (Binz et al., 2017; Quitzow et al., 2017; Varadi, 2014). In addition, manufacturing-related knowledge got increasingly embedded in automated production equipment (Huang et al., 2016; Huenteler et al., 2016). To start PV panel manufacturing nowadays, one does not have to acquire knowledge about all parts of the value chain, but needs to re-combine existing production machines to a working manufacturing line. After 2006, turnkey production lines appeared on the market that automated the whole production process from wafer slicing to module assembly, thereby further accelerating global knowledge circulation (Dewald and FromholdEisebith, 2015; Quitzow, 2013). Yet, to the Chinese pioneering firms in 2000, such turnkey solutions were not yet available (Quitzow, 2013; Zhang and White, 2016). They were forced to find other ways to access the technological capabilities needed for PV manufacturing. 


\section{Knowledge creation in China}

Knowledge and competencies in the Chinese solar PV sector strongly increased around 2000, when returnee entrepreneurs connected China to state-of-the-art international knowledge networks. In the case of Suntech, the founder was a world-renowned expert on PV technology from the University of New South Wales, who owned 15 technology patents and had developed a thin-film PV production line for an Australian company (Davila et al., 2010). When he established his start-up in Wuxi in 2001, he had accumulated both the theoretical knowledge and the practical know-how on state-of-the-art PV manufacturing technologies. Similar conditions applied to Canadian Solar, which was founded by a Sino-Canadian semiconductor technology expert that decided to outsource PV panel production of his Canadian start-up to Changzhou. Yingli and Trina were founded by domestic serial entrepreneurs, who had also accumulated extensive prior experience in export-oriented industries (de la Tour et al., 2011). The first annual reports of the four pioneering companies show that $70 \%$ of their senior management and board members had degrees from foreign universities and extensive work experience in international companies (Figure 4). As one of the founders of a pioneering Chinese PV company put it:

\footnotetext{
"It was very clear in my mind that I would start the company with the most updated [crystalline silicon] technology. Since 1989 I had spent 12 or 13 years in [foreign country], working on solar technology. I had accumulated a lot of knowledge and experience and I felt that I could do something dramatically different."
}

Figure 4: Master degrees of the board members of the four pioneering Chinese PV companies

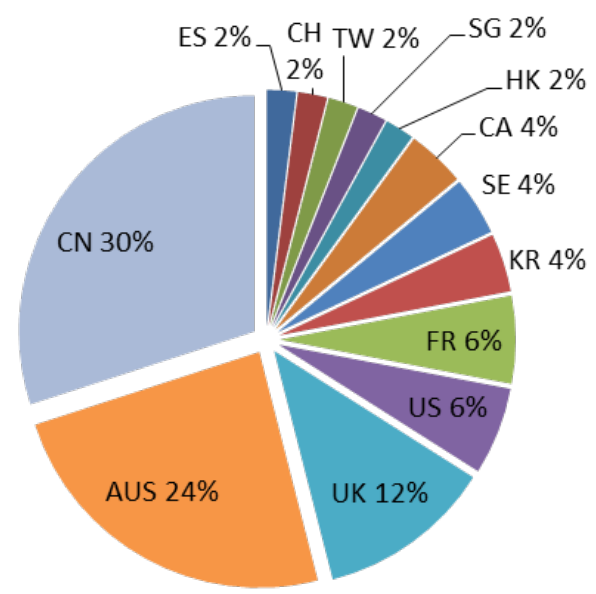

Source: Annual reports of Yingli, Trina, Suntech, Canadian Solar (2007), N=50 
When developing the first manufacturing lines, Chinese pioneers drew on a 'low cost expansion' strategy, which relied heavily on their international network connections (Davila et al., 2010; Zhang and White, 2016). Key components and machinery like wire saws or lamination machines were imported from abroad (Interviews 1, 2, 5, 9), and then adapted and combined with cheaper domestic components and materials (e.g. cover glass, cables) to form lower-cost, but still high-quality integrated production lines (Fu and Zhang, 2011). In several cases, second-hand production equipment was imported from Australian, Italian, or Japanese manufacturers with rebates of up to $90 \%$ (Interviews 10, 14, 21, Zhang and White, 2016).

At this early stage, China supplied the industry only with limited codified knowledge on solar PV manufacturing technology. The first integrated production lines could accordingly not be developed in partnership with local universities and research institutes, but were planned in close cooperation with foreign experts. In the case of Canadian Solar, the founder brought in key experts, PV production equipment and a management team from his previous position at Photowatt International (a then globally leading PV manufacturer based in France). In the case of Suntech, Australian experts from the University of New South Wales (UNSW) played a key role in establishing and fine-tuning the first production line.

"[Suntech] was relying on about 12 people [from UNSW] to set up the equipment, to fine tune the equipment, to commission it, to optimize the performance of it to get the product working properly. People from UNSW in the early stages directly provided all the technology support," (Interview 10)

Connections to UNSW remained instrumental for the Chinese industry also in later phases (de la Tour et al., 2011; Quitzow, 2015); Suntech and other Chinese companies funded research centers at this university and profited from free access to their intellectual property (Interview 10). One example was a virtual modelling tool for PV production lines that allowed the management of Suntech to virtually test and fine-tune all the parameters of their complex first production lines (Interview 10). Networks with the Photovoltaics Centre of Excellence turned into a key knowledge pipeline for the Chinese PV industry (de la Tour et al., 2011; Quitzow, 2015). Between 2001 and 2006, graduates from UNSW physically established the first production lines at Suntech, China Sunergy and JA Solar and experts increasingly circulated between various companies (Zhang and White, 2016). The Sino-Australian connections became so tight that investment banks that were organizing the IPO for Chinese companies (see section 4.5) were forcing them to hire board members that were graduates from UNSW (Interview 10). 
For more tacit forms of knowledge, both regional and international interaction was important. As the technological know-how for panel manufacturing is not prohibitively high, Chinese PV startups could rely on graduates from technical universities in China without PV technology expertise to support early operations:

\footnotetext{
“We hired only one experienced engineer from China. All the rest basically we hired as students, graduate students, and I would train them. We hired probably 1000. I'd spend two years training them. Three evening classes every week. I personally taught them lessons. [Their majors were in] science and engineering. Not related to solar."(Founder of a Chinese PV company)
}

The pioneering companies also engaged in upgrading the capabilities of the domestic supplier industry. Many (often farmer-run) local suppliers of steel frames, glass, welding materials or wiring cables lacked basic technological capabilities to produce high-quality inputs for PV panel production. The pioneering companies thus directly trained them, supported them in implementing ISO quality management procedures and sometimes even provided free patent licenses to increase their product quality.

"Some suppliers started from scratch. I taught them everything. I negotiate for them to buy equipment from Meyer-Burger for example. [...] It was all volunteering.” (Founder of a Chinese PV company)

Overall, decisive parts of the knowledge on PV manufacturing in the early 2000s did thus not originate from local Chinese sources. More importantly, the pioneering companies successfully mobilized international knowledge networks to upgrade existing generic capabilities in mass-manufacturing sectors, specialized supplier industries and the human capital from local universities.

\subsubsection{Market access}

\section{Market formation in the GIS}

From 1970 until 1990, solar PV modules were applied in niche markets like weather stations, oil platforms or calculators (Varadi, 2014; Zhao et al., 2013). These markets were too small to reap economies of scale in production and significantly reduce PV module prices. This situation changed in the late 1990s, when Japan, Germany and Spain initiated ambitious government-supported deployment subsidies. In Germany, grassroots movements successfully lobbied the regional and national government to spur market deployment with a regional and later national feed-in-tariff (FIT) system (Dewald and Truffer, 2012; Hoppmann et al., 2014; 
Peters et al., 2012). In Japan, from 1993 the Ministry of Economy, Trade and Industry (METI) embarked on a comprehensive R\&D and deployment subsidy for solar PV (the New Sunshine Project), in a strive to establish PV as a reliable national energy source (Vasseur et al., 2013). Especially Germany’s national FIT system in 2004 created the world’s first reliable mass market for solar PV modules which soared by $294 \%$ in that same year (Zhang et al., 2014). The policy-induced demand boom caused sharp global undersupply, as the German, Japanese, and U.S. incumbents could not address skyrocketing demand (Quitzow, 2015). As Quitzow (2015) illustrates, once this mass-market had been created, it turned into a system resource that was available to other PV manufacturers around the world.

\section{Market formation in China}

In China, PV module markets were largely inexistent until 2008 (Fischer, 2012; Zhang et al., 2014). Several deployment programs ${ }^{5}$ initiated by the central government and international donor agencies between 1995 and 2005 (Zhang et al., 2014) were not large enough to induce economies of scale in local production. The cumulative installed capacity in China only reached $52 \mathrm{MW}$ in 2003, compared to $140 \mathrm{MW}$ annual capacity additions in Germany alone (Quitzow, 2013). The Chinese market deployment policies furthermore brought to the fore considerable quality problems (Cabraal, 2004). Among the four pioneering Chinese manufacturers, Yingli and Trina were most active in these government-run programs. Yet, they used them not only for commercial purposes, but also for lobbying the central and local governments to back solar PV as part of their 'high-technology' support programs and longterm energy policy plans (Zhang and White, 2016).

The transnational entrepreneurs at Canadian Solar and Suntech were in turn in a favorable position to directly exploit new market opportunities forming abroad. Being deeply embedded in the global innovation system of the PV industry helped them to perceive a market opportunity that was not visible to their nationally embedded competitors:

\footnotetext{
“[In 2003], solar PV was still a small circle of experts. People were saying to us: 'Hey do you want to go to this German Intersolar show?' We did not know anything about it. They said it was good, so we said: 'okay, we will go and see' [...]. That was an eye opener for us. We had never been to a trade show before, and we loved it, we saw the products and we saw a lot of different customers who wanted to have these big PV modules for houses. So when we came back to China we started doing this right
}

\footnotetext{
${ }^{5}$ The most relevant programs by the Chinese government were the Township electrification program (from 2001) and the Brightness Program (from 1996).
} 
away." (Senior manager of a Chinese PV company)

To get access to the European and Japanese markets, Chinese startups swiftly established sales infrastructures abroad. At the early stages in 2003-2004, they scouted reliable sales partners and distributors at international trade fairs (Interviews 1, 2, 4, 8, 9). One company opened offices and service centers in three European countries and deployed more than 50 Chinese engineers for service and maintenance work. These teams were reporting back to the senior management in China on a weekly basis and briefing them about the requirements of Europe's high quality PV market. Before the global economic crisis stopped European market expansion in 2008, Chinese producers consistently exported more than $95 \%$ of their production to overseas markets (Fischer, 2012; Zhao et al., 2013).

In summary, also market-related system resources were initially largely sourced from a global level. Instead of struggling with sluggish market demand inside China and trying to construct new market segments in the complex institutional context of the Chinese power sector, the pioneering PV firms leveraged pre-existing trade infrastructure and their international personal networks to access booming markets in Europe and Japan. As a positive side-effect, the industry's early success in export market also significantly increased its lobbying power with national policy makers (cf. section 4.4.4).

\subsubsection{Financial investment}

Financial investment in the GIS

For a long time, mobilizing financial investment was a major challenge for solar PV firms. Between 1970 and 1990, financial investment for PV companies in the US, Europe and Japan was sourced from a rather erratic mix of angel investors, equity funds and large oil companies (Varadi, 2014). As long as the technology was in a niche market stadium, investors were reluctant to invest heavily in the industry and banks shied away from the considerable longterm risks related to PV investments (Hoppmann et al., 2014; Quitzow, 2013). This situation changed dramatically with the implementation of FIT systems in Japan and Germany. One of the main functions of feed-in tariffs was that they significantly decreased investment insecurities, which lead to a surge in annual demand-side investment from below 1 billion Euros in 2002 to 6.2 Billion Euro in 2008 (Quitzow, 2015). Regional banks, institutional investors and global investment banks moved into the PV sector and organized high profile IPOs of US and European PV companies like Q-cells, FirstSolar or Solarworld (Peters et al., 2012). By the early 2000s, various investors had accumulated sufficient sector expertise to 
target investment opportunities also in latecomer firms from Korea, Taiwan, Malaysia or China.

\section{Financial investment in China}

In China, the initial seed funding for the pioneering PV companies was raised predominantly from domestic sources (Dong et al., 2014; Zhang and White, 2016). It consisted of equity investment from the company founders, private donors, local municipalities, high-tech development zone administrations as well as state-owned enterprises (for a comprehensive discussion see Dong et al., 2014; Zhang and White, 2016). Local municipalities often took a coordinating role in attracting new companies to designated high-tech development zones and broker seed funding from local SOEs, regional banks or high-tech development zone management (Dong et al., 2014; Gallagher, 2014; Quitzow, 2015).

\footnotetext{
"In those days it was very hard to find investors. So I talked to mostly state-owned investors, in [several cities]. [...] I spent two weeks traveling around and talking to various investors and I finally thought, “it's possible." In [city X], everybody thought it was a good direction, a good area. They were one step ahead of time. So I came to the conclusion to start the company there, and when we actually started I thought it was a perfect time." (Founder of a Chinese PV company)
}

In the case of Suntech as an example, the Wuxi local government convinced seven local SOEs to invest a total of 5.2 million US\$, while the founder contributed 0.4M US\$ of his personal wealth as well as 1.6M US\$ worth of technology shares (Dong et al., 2014). In addition to direct seed funding, the startups also received generic support from local governments in the form of cheap land for production facilities, tax cuts or deficit guarantees from SOEs for lowinterest bank loans (Dong et al., 2014; Gallagher, 2014). Much of this support was not targeted specifically at PV ventures, but part of the general support schemes in high-tech support programs around the country (Zhang et al., 2014).

In the first years, having locally sourced seed investment was beneficial for the Chinese startups, but when the companies started embarking on a fast growth path in the mid-2000s, the limits of this state-controlled investment model became obvious (Davila et al., 2010; Zhang and White, 2016). Several company founders complained that their regional stateowned investors were drawing on too generic technological and financial expertise and thus refused to inject money, which considerably hampered the growth potential in international 
markets (Interviews 2, 9, 22). In 2004, international investors provided them with an opportunity to access financial resources from outside China.

"[By 2004] the company needed money. Our local stakeholders didn't really want to put in more money at the time. We needed access to the capital market. There were some American banks and investors that had followed us for more than a year, which I didn't realize."

- "Who approached you with the idea of an IPO?"

- "Some financial experts. Goldman Sachs, Morgan Stanley."

(Founder of a Chinese PV company)

Among the Chinese startups, Suntech became a pioneer in being listed at international stock markets ${ }^{6}$. To make an initial public offering possible, the founder needed to buy out the stateowned investors, who accepted based on a 13-times return on their initial investment (Zhang and White, 2016). Suntech's IPO in December 2005 was among the biggest technology IPO of the year, raising more than 400 million US\$ (Davila et al., 2010). American investment banks provided the know-how to prepare the public listing, helped restructure the company, added financial experts to its board of directors, and organized pre-IPO investor roadshows in the USA (Interviews 9, 10).

The spectacular success of Suntech motivated other Chinese PV manufacturers to equally list their shares at US stock exchanges (table 4). The investment raised from IPOs was an order of magnitude higher than what had been raised beforehand in the generic Chinese context (Dong et al., 2014; Gallagher, 2014; Quitzow, 2015; Zhang and White, 2016). Shortly after, also Chinese banks, private and institutional investors specialized in providing investments for this thriving business (Interviews 18, 20, 22, Dong et al., 2014). After the financial crisis in 2008, additional money from the Chinese stimulus package and Chinese development banks was pumped into the industry. With very cheap loans and capital costs, many Chinese companies considerably extended their debt ratio and started aggressively extending their production capacity (Quitzow, 2015).

\footnotetext{
${ }^{6}$ The company got listed at NYSE on 14 December 2005
} 
Table 4: Revenues from Initial Public Offerings of four pioneering PV manufacturers

\begin{tabular}{|c|c|c|c|c|c|}
\hline & Suntech & Trina & Canadian & Yingli & Total \\
\hline $\begin{array}{l}\text { IPO } \\
\text { place/year }\end{array}$ & $\begin{array}{c}2005 \\
\text { NYSE }\end{array}$ & $\begin{array}{c}2006 \\
\text { NYSE }\end{array}$ & $\begin{array}{c}2006 \\
\text { NASDAQ }\end{array}$ & $\begin{array}{c}2007 \\
\text { NYSE }\end{array}$ & \\
\hline $\begin{array}{l}\text { Pre-IPO } \\
\text { equity }\end{array}$ & \$96 mn. & $\$ 40 \mathrm{mn}$ & $\$ 12 \mathrm{mn}$ & $\$ 22 \mathrm{mn}$ & $\$ 170 \mathrm{mn}$. \\
\hline IPO revenue & \$395mn. & \$98mn. & $\$ 115 \mathrm{mn}$. & \$391mn. & $>$ \$1bn. \\
\hline
\end{tabular}

Source: Based on Quitzow (2013), Zhang and White (2016), company annual reports

Overall, our results confirm the findings from other studies that - even though seed funding was available inside China - the significant influx of outside investment from global capital markets in the mid-2000s was a key trigger for the subsequent fast expansion of the Chinese PV industry (de la Tour et al., 2011; Quitzow, 2015; Zhang and White, 2016). Also for financial investment, the pioneering companies did thus not only relate on the local context, but anchored investment resources and expertise from the GIS in their local structures. As a side effect, listing PV startups at foreign stock exchanges, also led to a dramatic improvement of the financial expertise and accounting practices in the pioneering Chinese firms.

\subsubsection{Legitimacy}

\section{Creation of legitimacy at a global level}

The last type of system resources of our framework, legitimacy, depends on aligning new products and industries with dominant cognitive, regulative and normative institutional structures (for an extensive discussion of the concept of technology and industry legitimacy, see e.g. Binz et al., 2016a; Markard et al., 2016; Suchman, 1995). Legitimizing the diffusion of solar power was not as challenging as for other energy technologies like nuclear power (Geels and Verhees, 2011). This notwithstanding, at the beginning of the industry formation process, PV entrepreneurs had to invest heavily in proving that solar power was not merely a dysfunctional niche technology, but able to compete with incumbent energy technologies in the long run (Jacobsson et al., 2004; Varadi, 2014). Skeptics emphasized the technology's high costs, missing market prospects, and long payback times that raised questions about PV plant's bankability (Peters et al., 2012). Among others, quality certification schemes became instrumental for addressing these arguments and legitimizing early claims about PV module's future performance levels (Varadi, 2014). 
Starting from 1970, the American PV module industry and NASA's Jet Propulsion Laboratory jointly developed the first comprehensive quality management system for PV module manufacturers, which later got included in a global ISO quality management standard (Varadi, 2014). Between 1980 and 2000, Underwriter laboratories (UL), TUV Rheinland, as well as the International Electrotechnical Commission (IEC) also developed challenging testing procedures for PV modules, which were designed to prove the high durability of these systems (Quitzow, 2013; Varadi, 2014). From 1990, and similar to the other resources, these standards and certification schemes turned into a globally available system resource, which could be used by latecomers to legitimize their quality claims both nationally and abroad.

\section{Technology legitimation in China}

The early Chinese industry had to struggle with two additional legitimacy problems. First, privately owned PV companies were a new institutional form in China's power sector, which had to be legitimized in a long-term collective lobbying effort (Zhang and White, 2016). Second, in the eyes of the central government, as well as domestic and international customers, the Chinese PV industry appeared illegitimate as it was prone with recurring product quality problems (Cabraal, 2004; Zhang and White, 2016). Chinese PV pioneers thus developed new narratives to prove that their products were worthy of the nation's high-tech support schemes and complying with international quality standards (Varadi, 2014; Zhang and White, 2016).

On the one hand, the early success of Chinese manufacturers in international markets and the successful IPOs overseas dramatically increased the industry's lobbying power vis-à-vis the regional and national governments (Zhang and White, 2016). On the other hand, foreign donor agencies and the Chinese central government also induced a Chinese quality certification program for PV systems in the early 2000s (Varadi, 2014). Yet, their first domestic quality label became available only after 2006 (Interview 19), at a time when the leading Chinese PV manufacturers were already targeting overseas markets. In 2002, the Chinese PV pioneers thus decided to base their manufacturing processes completely on existing European and American quality standards (Interviews 1, 4, 9). In the case of Suntech, UNSW was directly involved in helping the company comply with the demanding foreign quality requirements (Zhang and White, 2016). As a result, the company was able to present its first internationally certified products at a trade fair as early as 2003. 
"In Spring 2003 we had our first exhibition in Berlin. We were the only Asian company. People said, "hey, who is this guy, where did he come from?" [...] We were so proud. We had this international quality certification. No other Chinese company could do it. It had quite an impact in China." [Founder of a Chinese solar PV company]

Other Chinese companies quickly followed suit and used international quality certification for their manufacturing lines. By the mid-2000s the big four companies all had legitimized themselves to such a degree that they could sell their products in overseas markets and lobby key political decision makers in the central government (Quitzow, 2015; Zhang and White, 2016).

In summary, for technology legitimacy, the PV pioneers combined substantial institutional work inside China with positive spillovers from their close connections to resource formation processes in the global innovation system. Their efforts to associate Chinese PV products with international quality certificates and ISO management standards significantly improved the manufacturing and supplier industry’s product quality levels and, concomitantly, secured access to foreign markets. At the same time, the industry's impressive success in export markets coerced Chinese government officials and investors into explicitly supporting the industry.

\section{Discussion}

The results presented above show that the anchoring of external system resources played a key role in all four dimensions of our analytical framework. China's successful diversification into the solar PV industry has to be understood in the light of the early actor's outstanding capacity in connecting China's generic absorptive capacity with industry-specific system resources available elsewhere. Knowledge and market access were initially almost completely imported from other regions in the global innovation system, while financial investment and legitimacy developed inside China to some degree, but also with decisive support from international networks (table 5). 
Table 5: Origin of system resources for the early Chinese PV industry

\begin{tabular}{lcc}
\hline System resource & Domestic & International \\
\hline Knowledge & + & ++ \\
& small incumbent industry, basic research at \\
Chinese universities and research institutes & $\begin{array}{c}+ \text { technology and know-how } \\
\text { exchange with Australia, } \\
\text { Canada, Germany, Japan }\end{array}$ \\
Market access & domestic market support schemes not & + \\
& functional & sales to booming markets in \\
Financial & + & Germany, Spain, Japan \\
investment & generic support and seed funding by local & + \\
& governments, state owned enterprises and & IPOs at US stock markets \\
Legitimacy & regional banks & \\
& domestic quality certificate only emerging & quality certification in \\
& institutional entrepreneurship of the private PV & Germany, Spain, USA \\
\hline
\end{tabular}

0: no activity, +: weak activity, ++: strong activity

Overall, this pattern of industry formation differs from existing catching-up and related diversification models in several respects. First, domestic technology spillovers, local government support and R\&D programs played a role in the knowledge, market and investment dimensions, but taken alone can hardly explain China’s outstandingly fast path creation process. In the highly automated production process for PV panels, traditional laborcost advantages played a relatively minor role as well (Goodrich et al., 2013). We argue that the key comparative advantage of Chinese actors was stemming mostly from their international connections, the quick upscaling of operations with support from local governments and the fast emergence of a low-cost local supplier industry (also see Goodrich et al., 2013; Nahm, 2014). Thus, in contrast to what diversification theories assume, the pioneering companies did not build up their initial technological capabilities through related diversification, but by occupying a key brokerage position between cutting-edge international resource formation processes and rather generic (and initially technologically unrelated) manufacturing capabilities in China's coastal regions. 
Second, and in contrast to important accounts in catching-up literature, the pioneering actors in China did not build their capabilities through conventional technology transfer and FDIbased learning in the supplier networks of foreign lead firms. They rather transplanted - and innovated on (see Nahm and Steinfeld, 2014) - an emerging industrial path by substituting missing local capabilities with direct access to international resources through variegated channels of 'non-conventional' technology transfer (Lema and Lema, 2016; Lema and Lema, 2012). Figure 5 further specifies these channels. Knowledge was accessed and anchored from Australia through a knowledge pipeline with the University of New South Wales, but was also embedded in machinery components that were recycled from European and Japanese manufacturers. Markets were mostly accessed through establishing sales representative offices in Germany, Japan and Spain. Investment was raised inside China, but also from global stock markets as well as by cooperating with investment banks and VC investors from Hong Kong, Europe and the USA. Legitimacy for the emerging industry was constructed inside China itself, but entrepreneurs also leveraged quality certification from the USA, Europe and international NGOs (ISO, IEC and the World Bank). 
Figure 5: Spatial origin of key system resources for the Chinese solar PV industry

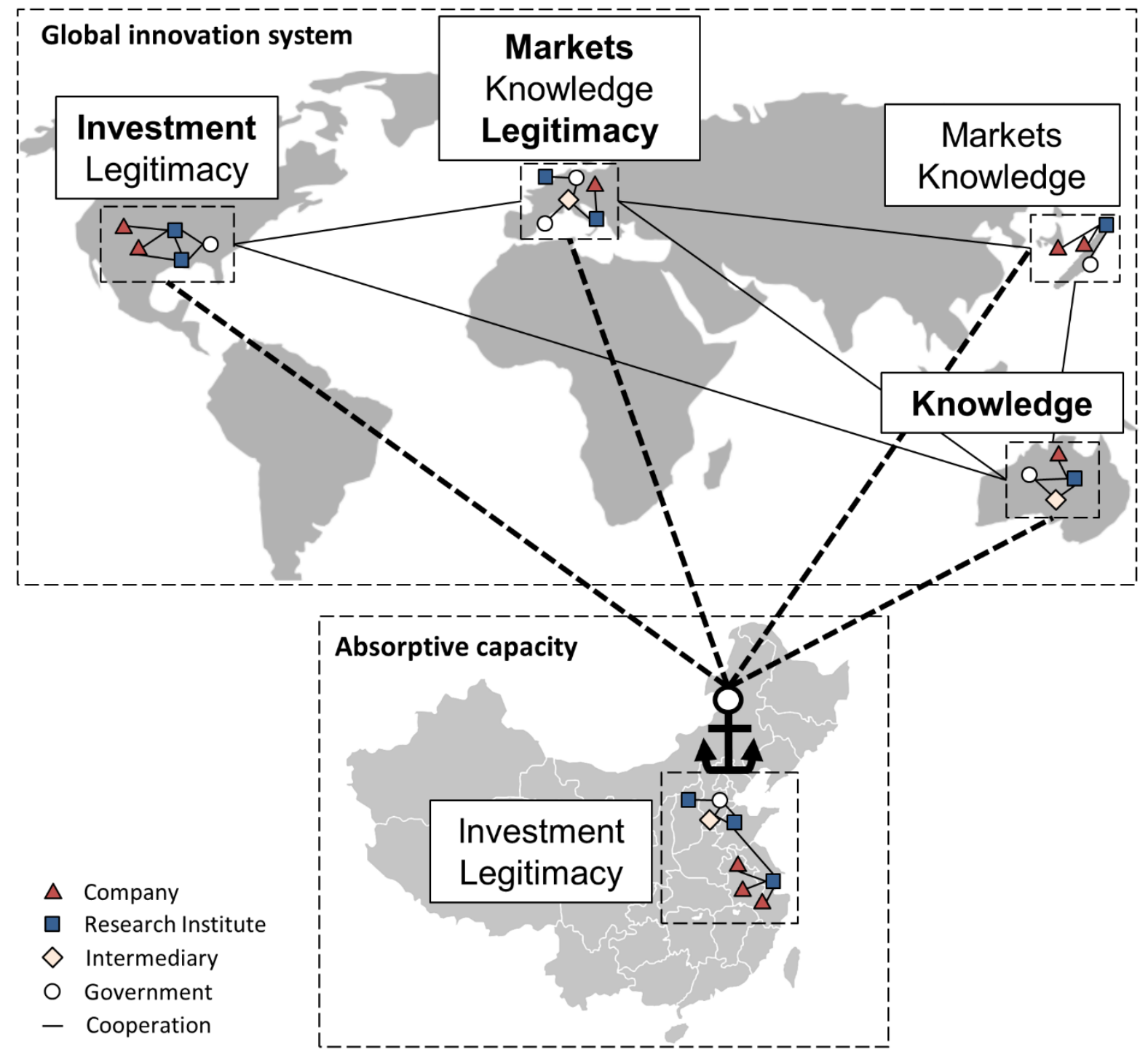

Source: Own design, bold words indicate key origins of system resources for the Chinese industry

From 2000-2008 this led to the unexpected situation that a new cleantech industry was forming and quickly upscaling operations in China, even though markets, key technological capabilities and a supportive innovation system had formed locally only to a very limited degree. At this early stage, the industry was also not pushed by a strategic policy program or price dumping practices by the central government. This situation changed dramatically after 2008, when the Chinese government scaled-up industry support in various dimensions (Huang et al., 2016; Iizuka, 2015; Zhi et al., 2014). Still, at the time when strategic deployment policies emerged at a national level, the pioneering companies had already established global pipelines and transformed the local resource base to facilitate further expansion and capability upgrading in the Chinese PV industry. In summary, this model of industry formation in our interpretation lies at the intersection of 'transplantation from elsewhere' (Boschma et al., 
2017; Martin and Sunley, 2006) and 'saltation‘ (Boschma et al., 2017) or 'path-creating catching-up’ (Lee and Lim, 2001).

This new model contrasts starkly with that of e.g. the Chinese wind power industry, in which central government policies and spillovers from related domestic industries played a major role from the start (Quitzow et al., 2017; Surana and Anadon, 2015). Our results support recent arguments from industry lifecycle scholars that the availability of system resources at the global level and the ability of entrepreneurs to access them are conditioned by an industry’s technology and product characteristics (Quitzow et al., 2017; Schmidt and Huenteler, 2016). PV panels are a standardized, easily shippable, and mass-manufactured product with an analytic knowledge base and relatively predictable technological trajectory (Huenteler et al., 2016). These characteristics all increase the potential for international knowledge circulation and lower the entrance barriers for latecomers (Schmidt and Huenteler, 2016). The solar PV industry can accordingly be related to a 'footloose' GIS type (Binz et al., 2017). Similar industry formation trajectories seem most realistic for industries with comparable innovation modes and valuation systems (like consumer electronics or standard pharmaceuticals). Whether and how anchoring-based unrelated diversification is possible in industries with spatially ‘sticky’ GIS architectures (like wind power or biofuels) is an interesting open empirical question.

\section{Conclusions}

This paper further specified and tested an analytical framework for analyzing unrelated diversification processes in latecomer contexts. The conceptual discussion and empirical results revealed a new industry formation model, which relies more strongly on unrelated absorptive capacities and international interdependencies than what existing catching-up and related diversification theories expect. Our analytical framework broadened the focus of these literatures beyond (mostly knowledge- and firm-based) industrial upgrading to a wider systemic environment that includes market dynamics, investor's interests, and institutional embedding of new technologies. We argue that such an approach is crucial for further specifying the variegated non-conventional technology transfer mechanisms that are involved in unrelated diversification (and cleantech industry formation) processes in latecomer countries. 
Our empirical results allow for a slightly more optimistic view on the potential of latecomer countries in making medium-to-long jumps in the product space (also see Zhu et al., 2017). In the Chinese solar PV case, directly related industries were almost inexistent at the outset, but Chinese PV companies still managed to develop into a global lead firm position in less than ten years. Our study thus supports the view of Perez et al. (1985) that especially the formative phase of new technological paradigms (like emerging cleantech industries in the 'green' economy) may present a window of opportunity for latecomers with basic generic absorptive capacity to enable unrelated diversification processes similar to the Chinese PV experience. This finding implies a strong need for sustainability transition studies to expand their analytical focus to leapfrogging-type industry dynamics in developing and emerging economies. If similar dynamics are observable in other cleantech industries, the center of gravity in various sector's sustainability transitions is likely to shift dramatically in space in the near-to-mid-term future.

Our findings also open new rationales for policymaking. In our empirical case, successful unrelated diversification depended on three key ingredients: generic absorptive capacity in the latecomer country, globally available system resources, and actors that are able to link these two elements. Existing policy approaches focus mostly on improving the first dimension and tend to downplay the latter two. Understanding global system formation dynamics, creating effective links to extra-regional system resources and incentivizing the repatriation of highly skilled technology experts are policy strategies that seem to deserve closer attention in this respect. In addition, analyzing the regional and international formation process for each system resource could be used to identify bottlenecks (system building and international interaction failures) that could then be used to justify targeted national/regional policy interventions and/or novel global governance schemes (Binz and Truffer, 2017; Jacobsson and Bergek, 2011; Weber and Rohracher, 2012).

It goes without saying that our analysis also has important limitations that warrant future research. First and foremost, the generalizability of our results is limited by the single case study design focusing on the solar PV industry and on China. We do accordingly not claim (statistical) generalizability to our empirical results, but analytical generalizability to our framework and the detailed account of an unrelated diversification process. The analytical dimensions provide a useful heuristic for studies in other sectors and national contexts. 
Future comparative studies could explore why industry transplantation succeeded in mainland China and not in other latecomer countries (e.g. India, Malaysia, Taiwan) which may have had comparable initial generic absorptive capacity and local innovation system structures in place. Further research is clearly needed to disentangle in more detail what parts of the industry transplantation process are attributable to parts of China's generic absorptive capacity for mass-manufacturing that may be unique to its institutional context (and which not) and how the importance of generic absorptive capacity differs between countries. For example, it may be that other countries, which have not developed the fast manufacturing scale-up capabilities documented by Nahm and Steinfeld (2014), or which have not had similar local level generic manufacturing support, may not be able to emulate the Chinese PV experience.

Moving on to the 'industry-specific' system resources, most of which were international in our empirical case, it could be the case that not every country could equally mobilize them. For example, organizing IPOs in the USA was only possible after considerable institutional and organizational re-arrangements inside China, and Chinese firms may have had specific competitive advantages in accessing the German solar PV market (see Quitzow, 2015). In short, future work could try to determine the extent to which other countries have similar generic absorptive capacities or access to the (highly internationalized) industry-specific resources.

In addition, future work could try to determine to what extent the resources, both generic and industry specific, identified in this case are important or applicable to other technologies. Here, the recent work of industry lifecycle and innovation system scholars (Binz and Truffer, 2017; Huenteler et al., 2016; Quitzow et al., 2017) provides a useful comparative heuristic. We encourage other authors to contribute to a comprehensive set of case studies similar to the one presented here, which also cover 'market-anchored', 'production anchored' and 'spatially sticky’ industry types (Binz and Truffer, 2017). Ultimately, such a collective effort could lead to a highly relevant process theory on unrelated diversification and path-creating catching-up that is valid beyond the formative phase, which was in focus here.

\section{Acknowledgements}

The authors would like to thank the Sustainability Science Program at Harvard Kennedy School and the Swiss National Science Foundation (Early Postdoc.Mobility Grant 
P2BEP1_155474) for funding this project. Xia Di and Prof. Su Jun were of invaluable support in hosting one of the authors at SPPM, Qinghua University, and in organizing high-level expert interviews in China. Special thanks also to Christopher Cote for collecting background materials and supporting the fieldwork campaign. This article furthermore profited from constructive input at the Geneva Dialogue Lecture in 2015, the IST conference 2015, the AAG annual meeting 2015, the HKS Energy Policy Seminar 2015, as well as a CIRCLE seminar, two SSP Fellow Seminars, an IKE seminar at the University of Aalborg and a workshop on related variety and the product space at the Harvard Centre for International Development in 2015. The authors would like to thank all their interviewees, the anonymous reviewers, the editor of EIST, and, in particular, Markus Grillitsch, Koen Frenken, Bernhard Truffer, Rob Raven, Tang Tian and Lars Coenen for their constructive and helpful inputs on earlier drafts of this article. This work was partially conducted while one of the authors was a Giorgio Ruffolo Post-Doctoral Fellow in the Sustainability Science Program at Harvard University. Support from Italy’s Ministry for Environment, Land and Sea is gratefully acknowledged. 


\section{Appendix 1: Interviewees}

\begin{tabular}{|c|c|c|c|}
\hline Number & Organization & Chinese Name & Experts interviewed \\
\hline 1 & Canadian Solar & $\begin{array}{l}\text { 阿特斯阳光电力集 } \\
\text { 团 }\end{array}$ & Senior manager, member of the founding team \\
\hline $2-4$ & Trina Solar & $\begin{array}{l}\text { 阿特斯阳光电力集 } \\
\text { 团 }\end{array}$ & $\begin{array}{l}\text { CTO } \\
\text { Senior financial manager } \\
\text { Project engineer }\end{array}$ \\
\hline $5-7$ & Yingli Solar & $\begin{array}{l}\text { 英利绿色能源控股 } \\
\text { 有限公司 }\end{array}$ & $\begin{array}{l}\text { Founder, CEO } \\
\text { CTO } \\
\text { Financial manager }\end{array}$ \\
\hline 8 & Jinko Solar & $\begin{array}{l}\text { 晶科能源控股有限 } \\
\text { 公司 }\end{array}$ & Head of global market development \\
\hline $9-10$ & Suntech & $\begin{array}{l}\text { 无锡尚德太阳能电 } \\
\text { 力有限公司 }\end{array}$ & $\begin{array}{l}\text { Founder, former CEO } \\
\text { Former CTO }\end{array}$ \\
\hline 11 & Qinghua Solar & 清华光伏 & Senior Vice President \\
\hline 12 & Solarex & $\mathrm{n} / \mathrm{a}$ & Founder, former CEO \\
\hline 13 & Hareon Solar & 海润光伏 & СТO \\
\hline 14 & $\begin{array}{l}\text { Shanghai Solar } \\
\text { Energy Science \& } \\
\text { Technology Co. Ltd. }\end{array}$ & $\begin{array}{l}\text { 上海太阳能科技 } \\
\text { 有限公司 }\end{array}$ & Former chief manager \\
\hline 15 & $\begin{array}{l}\text { Energy Research } \\
\text { Institute of the NDRC }\end{array}$ & $\begin{array}{l}\text { 国家发展和改革委 } \\
\text { 员会能源研究所 }\end{array}$ & Senior Manager \\
\hline 16 & $\begin{array}{l}\text { China Solar PV } \\
\text { Association }\end{array}$ & 中国光伏行业协会 & Director \\
\hline 17 & $\begin{array}{l}\text { China Renewable } \\
\text { Energy Industry } \\
\text { Association (CREIA) }\end{array}$ & $\begin{array}{l}\text { 中国可再生能源行 } \\
\text { 业协会 }\end{array}$ & Senior manager \\
\hline 18 & Greenpeace China & 中国绿色和平 & Senior manager \\
\hline 19 & $\begin{array}{l}\text { China General } \\
\text { Certification Center } \\
\text { (CGC) }\end{array}$ & 北京鉴衡认证中心 & Director \\
\hline $20-23$ & Qinghua University & 清华大学 & 4 professors and assistant professors \\
\hline $24-25$ & $\begin{array}{l}\text { North China Electric } \\
\text { Power University }\end{array}$ & 华北电力大学 & 2 professors \\
\hline 26 & $\begin{array}{l}\text { Chinese Academy of } \\
\text { Sciences }\end{array}$ & 中国科学院 & 1 professor \\
\hline
\end{tabular}




\section{References}

Altenburg, T., Schmitz, H., Stamm, A., 2008. Breakthrough? China's and India's Transition from Production to Innovation. World Development 36 (2), 325-344.

Amsden, A.H., 1992. Asia's next giant: South Korea and late industrialization. Oxford University Press on Demand.

Bathelt, H., Glückler, J., 2005. Resources in economic geography: From substantive concepts towards a relational perspective. Environment and Planning A 37 (9), 1545-1563.

Bening, C.R., Blum, N.U., Schmidt, T.S., 2015. The need to increase the policy relevance of the functional approach to Technological Innovation Systems (TIS). Environmental Innovation and Societal Transitions, 16, 73-75.

Bergek, A., Jacobsson, S., Carlsson, B., Lindmark, S., Rickne, A., 2008. Analyzing the functional dynamics of technological innovation systems: A scheme of analysis. Research Policy 37 (3), 407-429.

Binz, C., Tang, T., Huenteler, J., 2017. Spatial Lifecycles of Cleantech Industries - the Global Development History of Solar Photovoltaics. Energy Policy 101, 386-402.

Binz, C., Truffer, B., 2017. Global Innovation Systems-A conceptual framework for innovation dynamics in transnational contexts. Research Policy 64 (7), 1284-1298.

Binz, C., Sedlak, D., Harris-Lovett, S., Kiparsky, M., Truffer, B., 2016a. The thorny road to technology legitimation - Institutional work for potable water reuse in California.

Technological Forecasting \& Social Change 103, 249-263.

Binz, C., Truffer, B., Coenen, L., 2016b. Path creation as a process of resource alignment and anchoring - Industry formation for on-site water recycling in Beijing. Economic Geography 92 (2), 172-200.

Binz, C., Truffer, B., Li, L., Shi, Y., Lu, Y., 2012. Conceptualizing leapfrogging with spatially coupled innovation systems: The case of onsite wastewater treatment in China. Technological Forecasting and Social Change 79 (1), 155-171.

Boschma, R., Coenen, L., Frenken, K., Truffer, B., 2017. Towards a theory of regional diversification. Regional Studies 51 (1), 31-45.

Boschma, R., Minondo, A., Navarro, M., 2012. Related variety and regional growth in Spain. Papers in Regional Science 91 (2), 241-256.

Bruce, Anna, 2007. Capability Building for the Manufacture of Photovoltaic System Components in Developing Countries. PhD thesis. School of Photovoltaics and Renewable Energy Engineering, The University of New South Wales, Sydney, Australia.

Cabraal, A., 2004. Strengthening PV businesses in China - A World Bank renewable energy development project. Renewable Energy World (May-June), 126-139. 
Chaminade, C., Plechero, M., 2015. Do regions make a difference? Regional innovation systems and global innovation networks in the ICT industry. European Planning Studies 23 (2), 215-237.

Choi, H., Anadon, L.D., 2013. The role of the complementary sector and its relationship with network formation and government policies in emerging sectors: The case of solar photovoltaics between 2001 and 2009. Technological Forecasting and Social Change 82, 8094.

Coe, N., Yeung, H.W., 2015. Global Production Networks: Theorizing Economic Development in an Interconnected World. Oxford University Press, Croydon (UK).

Coe, N.M., Bunnell, T.G., 2003. 'Spatializing' knowledge communities: towards a conceptualization of transnational innovation networks. Global Networks 3 (4), 437-456.

Coenen, L., Benneworth, P., Truffer, B., 2012. Toward a spatial perspective on sustainability transitions. Research Policy 41 (6), 968-979.

Cohen, W.M., Levinthal, D.A., 1989. Innovation and learning: the two faces of R\&D. Economic Journal 99 (397), 569-596.

Crevoisier, O., Jeannerat, H., 2009. Territorial knowledge dynamics: From the proximity paradigm to multi-location milieus. European Planning Studies 17 (8), 1223-1241.

Curran, L., 2015. The impact of trade policy on global production networks: the solar panel case. Review of International Political Economy (ahead-of-print), 1-30.

Dahlman, C., Nelson, R., 1995. Social absorption capability, national innovation systems and economic development. In: Perkins, D.H., Koo, B.H. (Eds.), Social capability and long-term growth. Macmillan Press, Basingstoke.

Davila, A., Foster, G., Jia, N., 2010. Suntech Power Holdings (A): The Pre-IPO Years. Stanford Graduate School of Business, Palo Alto, CA.

Dawley, S., 2014. Creating new paths? Offshore wind, policy activism, and peripheral region development. Economic Geography 90 (1), 91-112.

de la Tour, A., Glachant, M., Ménière, Y., 2011. Innovation and international technology transfer: The case of the Chinese photovoltaic industry. Energy Policy 39 (2), 761-770.

Dewald, U., Truffer, B., 2012. The Local Sources of Market Formation: explaining regional growth differentials in German photovoltaic markets. European Planning Studies (3), 397420.

Dewald, U., Truffer, B., 2011. Market Formation in Technological Innovation Systems Diffusion of Photovoltaic Applications in Germany. Industry and Innovation 18 (3), 285-300.

Dewald, U., Fromhold-Eisebith, M., 2015. Trajectories of sustainability transitions in scaletranscending innovation systems: The case of photovoltaics. Environmental Innovation and Societal Transitions 17, 110-125. 
Dong, W., Qi, Y., Spratt, S., 2014. The Political Economy of Low-Carbon Investment: The Role of Coalitions and Alignments of Interest in the Green Transformation in China. Climate Policy Institute, Tsinghua University, Beijing, China.

Drori, I., Honig, B., Wright, M., 2009. Transnational entrepreneurship: An emergent field of study. Entrepreneurship: Theory and Practice 33 (5), 1001-1022.

Energy Research Institute, 2000. Commercialization of solar PV Systems in China. Center for Renewable Energy Development, National Development and Reform Commission, Beijing, China.

Evans, P.B., 1995. Embedded autonomy: states and industrial transformation. Princeton University Press, Princeton, NJ.

Fischer, D., 2012. Challenges of low carbon technology diffusion: insights from shifts in China's photovoltaic industry development. Innovation and Development 2 (1), 131-146.

Freeman, C., 1987. Technology and economic performance: lessons from Japan. Pinter, London.

Frenken, K., Boschma, R.A., 2007. A theoretical framework for evolutionary economic geography: Industrial dynamics and urban growth as a branching process. Journal of Economic Geography 7 (5), 635-649.

Fu, X., Pietrobelli, C., Soete, L., 2011. The role of foreign technology and indigenous innovation in the emerging economies: technological change and catching-up. World Development 39 (7), 1204-1212.

Fu, X., Zhang, J., 2011. Technology transfer, indigenous innovation and leapfrogging in green technology: The solar-PV industry in China and India. Journal of Chinese Economic and Business Studies 9 (4), 329-347.

Gallagher, K.S., 2014. The Globalization of Clean Energy Technology - Lessons from China. MIT press, Cambridge, MA.

Geels, F.W., Verhees, B., 2011. Cultural legitimacy and framing struggles in innovation journeys: A cultural-performative perspective and a case study of Dutch nuclear energy (1945-1986). Technological Forecasting and Social Change 78 (6), 910-930.

Gereffi, G., Humphrey, J., Sturgeon, T., 2005. The governance of global value chains. Review of international political economy 12 (1), 78-104.

Gereffi, G., 1999. International trade and industrial upgrading in the apparel commodity chain. Journal of International Economics 48 (1), 37-70.

Goodrich, A.C., Powell, D.M., James, T.L., Woodhouse, M., Buonassisi, T., 2013. Assessing the drivers of regional trends in solar photovoltaic manufacturing. Energy and Environmental Science 6 (10), 2811-2821. 
Gosens, J., Lu, Y., Coenen, L., 2015. The role of transnational dimensions in emerging economy 'Technological Innovation Systems' for clean-tech. Journal of Cleaner Production 86 (1), 378-388.

Gosens, J., Lu, Y., 2013. From lagging to leading? Technological innovation systems in emerging economies and the case of Chinese wind power. Energy Policy 60, 234-250.

He, C., Yan, Y., Rigby, D., 2016. Regional industrial evolution in China. Papers in Regional Science.

Hekkert, M., Suurs, R., Negro, S., Kuhlmann, S., Smits, R., 2007. Functions of innovation systems: A new approach for analysing technological change. Technological Forecasting and Social Change 74 (4), 413-432.

Hidalgo, C.A., Winger, B., Barabási, A.-., Hausmann, R., 2007. The product space conditions the development of nations. Science 317 (5837), 482-487.

Hirschman, A.O., 1968. The political economy of import-substituting industrialization in Latin America. The Quarterly Journal of Economics 82 (1), 1-32.

Hoppmann, J., Huenteler, J., Girod, B., 2014. Compulsive policy-making-The evolution of the German feed-in tariff system for solar photovoltaic power. Research Policy 43 (8), 14221441.

Huang, P., Negro, S.O., Hekkert, M.P., Bi, K., 2016. How China became a leader in solar PV: An innovation system analysis. Renewable and Sustainable Energy Reviews 64, 777-789.

Huenteler, J., Schmidt, T., Ossenbrink, J., Hoffmann, V., 2016. Technology Life-Cycles in the Energy Sector - Technological Characteristics and the Role of Deployment for Innovation. Technological Forecasting \& Social Change 104, 102-121.

Iizuka, M., 2015. Diverse and uneven pathways towards transition to low carbon development: the case of solar PV technology in China. Innovation and Development 5 (2), 241-261.

Jacobsson, S., Bergek, A., 2011. Innovation system analyses and sustainability transitions: Contributions and suggestions for research. Environmental Innovation and Societal Transitions 1 (1), 41-57.

Jacobsson, S., Sandén, B.A., Bångens, L., 2004. Transforming the energy system-the evolution of the German technological system for solar cells. Technology Analysis and Strategic Management 16 (1), 3-30.

Jung, M., Lee, K., 2010. Sectoral systems of innovation and productivity catch-up: determinants of the productivity gap between Korean and Japanese firms. Industrial and Corporate Change 19 (4), 1037-1069.

Lall, S., 1992. Technological capabilities and industrialization. World Development 20 (2), 165-186. 
Lee, K., Lim, C., 2001. Technological regimes, catching-up and leapfrogging: findings from the Korean industries. Research Policy 30 (3), 459-483.

Lema, A., Lema, R., 2016. Low-carbon innovation and technology transfer in latecomer countries: Insights from solar PV in the clean development mechanism. Technological Forecasting and Social Change 104, 223-236.

Lema, R., Lema, A., 2012. Technology transfer? The rise of China and India in green technology sectors. Innovation and Development 2 (1), 23-44.

Lewis, J.I., 2011. Building a national wind turbine industry: Experiences from China, India and South Korea. International Journal of Technology and Globalisation 5 (3-4), 281-305.

Li, D., 2009. The solar power sector in China. LRI Energy Paper, London Research International, available at: http://www.doc88.com/p-718479322457.html, 15.10.2015.

Liu, W., Dicken, P., 2006. Transnational corporations and "obligated embeddedness": foreign direct investment in China's automobile industry. Environment and Planning A, 38, 12291247.

Lundvall, B., Vang, J., Joseph, K.J., Chaminade, C., 2009. Innovation system research and developing countries. In: Lundvall, B., Joseph, K.J., Chaminade, C., Vang, J. (Eds.), Handbook of Innovation Systems and Developing Countries. Edward Elgar, Cheltenham, UK, pp. 1-30.

MacKinnon, D., 2012. Beyond strategic coupling: reassessing the firm-region nexus in global production networks. Journal of Economic Geography 12 (1), 227-245.

Malerba, F., Nelson, R., 2011. Learning and catching up in different sectoral systems: evidence from six industries. Industrial and Corporate Change 20 (6), 1645-1675.

Markard, J., Wirth, S., Truffer, B., 2016. Institutional dynamics and technology legitimacy A framework and a case study on biogas technology. Research Policy 45 (1), 330-344.

Markard, J., Raven, R., Truffer, B., 2012. Sustainability transitions: An emerging field of research and its prospects. Research Policy 41 (6), 955-967.

Martin, R., 2010. Roepke Lecture in Economic Geography—Rethinking Regional Path Dependence: Beyond Lock-in to Evolution. Economic Geography 86 (1), 1-27.

Martin, R., Sunley, P., 2006. Path dependence and regional economic evolution. Journal of economic geography 6 (4), 395-437.

Maskell, P., Malmberg, A., 1999. The competitiveness of firms and regions. 'Ubiquitification' and the importance of localized learning. European Urban and Regional Studies 6 (1), 9-25.

Mathews, J.A., 2006. Dragon multinationals: New players in 21 st century globalization. Asia Pacific journal of management 23 (1), 5-27.

Mazzucato, M., 2015. The entrepreneurial state: Debunking public vs. private sector myths. Anthem Press. 
Morrison, A., Pietrobelli, C., Rabellotti, R., 2008. Global value chains and technological capabilities: a framework to study learning and innovation in developing countries. Oxford development studies 36 (1), 39-58.

Musiolik, J., Markard, J., 2011. Creating and shaping innovation systems: Formal networks in the innovation system for stationary fuel cells in Germany. Energy Policy 39, 1909-1922.

Musiolik, J., Markard, J., Hekkert, M., 2012. Networks and network resources in technological innovation systems: Towards a conceptual framework for system building. Technological Forecasting and Social Change 79 (6), 1032-1048.

Nahm, J., 2014. “The Role of Innovative Manufacturing in High-Tech Product Development: Evidence from China's Renewable Energy Sector”. In: Locke, R., Wellhausen, R. (Eds.), Production in the Innovation Economy. MIT Press, Cambridge, MA, pp. 139-174.

Nahm, J., Steinfeld, E.S., 2014. Scale-up Nation: China's Specialization in Innovative Manufacturing. World Development 54, 288-300.

Narula, R., 2004. Understanding absorptive capacities in an "innovation systems" context: consequences for economic and employment growth. UNU-MERIT Research Memoranda., UNU-MERIT, Maastricht, NL. Available online at: http://collections.unu.edu/eserv/UNU:1155/rm2004-003.pdf.

Neffke, F., Hartog, M., Boschma, R., Henning, M., 2014. Agents of structural change. The role of firms and entrepreneurs in regional diversification. Papers in Evolutionary Economic Geography, Utrecht University 14.10.

Neffke, F., Henning, M., Boschma, R., 2011. How Do Regions Diversify over Time? Industry Relatedness and the Development of New Growth Paths in Regions. Economic Geography 87 (3), 237-265.

Nelson, R., 1993. National Innovation Systems: A Comparative Analysis. Oxford University Press, New York.

Perez, C., 1985. Microelectronics, long waves and world structural change: New perspectives for developing countries. World Development 13 (3), 441-463.

Peteraf, M., 2005. A Resource-Based Lens on Value Creation, Competitive Advantage, and Multi-Level Issues in Strategic Management Research. In: Fred Dansereau, F.J.Y. (Ed.), Research in Multi-Level Issues, JAI, pp. 177-188.

Peters, M., Schneider, M., Griesshaber, T., Hoffmann, V.H., 2012. The impact of technologypush and demand-pull policies on technical change-Does the locus of policies matter? Research Policy 41 (8), 1296-1308.

Pinheiro, F.L., Alshamsi, A., Hartmann, D., Boschma, R., Hidalgo, C., 2018. Shooting Low or High: Do Countries Benefit from Entering Unrelated Activities? arXiv:1801.05352 [qfin.GN].

Quitzow, R., 2013. The Co-evolution of Policy, Market and Industry in the Solar Energy Sector - A Dynamic Analysis of Technological Innovation Systems for Solar Photovoltaics in 
Germany and China . FFU Report 06 - 2013, Forschungszentrum für Umweltpolitik, Freie Universität Berlin.

Quitzow, R., 2015. Assessing policy strategies for the promotion of environmental technologies: A review of India's National Solar Mission. Research Policy 44 (1), 233-243.

Quitzow, R., Huenteler, J., Asmussen, H., 2017. Development trajectories in China's wind and solar energy industries: How technology-related differences shape the dynamics of industry localization and catching up. Journal of Cleaner Production available online. DOI: 10.1016/j.jclepro.2017.04.130.

Quitzow, R., 2015. Dynamics of a policy-driven market: The co-evolution of technological innovation systems for solar photovoltaics in China and Germany. Environmental Innovation and Societal Transitions 17, 126-148.

Rock, M.T., Murphy, J.T., Rasiah, R., van Seters, P., Managi, S., 2009. A hard slog, not a leap frog: Globalization and sustainability transitions in developing Asia. Technological Forecasting \& Social Change, 76 (2), 241-254.

Sauter, R., Watson, J., 2008. Technology Leapfrogging: A Review of the Evidence. University of Sussex, Sussex Energy Group, Science and Technology Policy Research (SPRU).

Saxenian, A., 2007. The new argonauts: Regional advantage in a Global Economy. Harvard University Press, Boston, MA.

Schmidt, T.S., Huenteler, J., 2016. Anticipating industry localization effects of clean technology deployment policies in developing countries. Global Environmental Change 38, 820.

Sengers, F., Raven, R., 2015. Toward a spatial perspective on niche development: The case of Bus Rapid Transit. Environmental Innovation and Societal Transitions 17, 166-182.

SIA, 2014. Semiconductor Industry Association 2014 Factbook. Semiconductor Industry Association, Washington, DC.

Simmie, J., 2013. Path dependence and new technological path creation in the economic landscape. In: Cooke, P. (Ed.), Re-Framing Regional Development. Routledge, New York, pp. 164-185.

Strauss, A., Corbin, J., 1998. Basics of Qualitative Research. (2), Sage Publications, Thousand Oaks.

Suchman, M.C., 1995. Managing legitimacy: Strategic and Institutional Approaches. Academy of Management Review 20 (3), 571-610.

Surana, K., Anadon, L.D., 2015. Public Policy and Financial Resource Mobilization for Wind Energy in Developing Countries: A Comparison of Approaches and Outcomes in China and India. Global Environmental Change 35, 340-359. 
Tanner, A.N., 2014. Regional Branching Reconsidered: Emergence of the Fuel Cell Industry in European Regions. Economic Geography 90 (4), 403-427.

Varadi, P., 2014. Sun Above the Horizon: Meteoric Rise of the Solar Industry. Pan Stanford Publishing, Singapore.

Vasseur, V., Kamp, L.M., Negro, S.O., 2013. A comparative analysis of Photovoltaic Technological Innovation Systems including international dimensions: The cases of Japan and the Netherlands. Journal of Cleaner Production 48, 200-210.

Wade, R., 2004. Governing the market: economic theory and the role of government in East Asian industrialization. (2nd edition), Princeton University Press, Princeton, NJ.

Wade, R., 1988. The role of government in overcoming market failure: Taiwan, Republic of Korea and Japan. Achieving Industrialization in East Asia, 129-163.

Weber, K.M., Rohracher, H., 2012. Legitimizing research, technology and innovation policies for transformative change: Combining insights from innovation systems and multi-level perspective in a comprehensive ‘failures' framework. Research Policy 41 (6), 1037-1047.

Wenger, E., 1998. Communities of practice - Learning, meaning, and identity. Cambridge University Press, Cambridge, UK.

Wieczorek, A.J., Hekkert, M.P., Coenen, L., Harmsen, R., 2015. Broadening the national focus in technological innovation system analysis: The case of offshore wind. Environmental Innovation and Societal Transitions 14, 128-148.

Witt, M., 2014. China: Authoritarian Capitalism. In: Witt, M., Redding, G. (Eds.), The Oxford Handbook of Asian Business Systems. Oxford University Press, New York, NY, USA, pp. 11-33.

Xielin, L., 2005. China’s Development Model: An Alternative Strategy for Technological Catch-Up. Research Institute of Economy, Trade and Industry.

Yang, H., Wang, H., Yu, H., Xi, J., Cui, R., Chen, C., 2003. Status of photovoltaic industry in China. Energy Policy 31 (8), 703-707.

Yeung, H.W., Coe, N.M., 2015. Toward a dynamic theory of global production networks. Economic Geography 91 (1), 29-58.

Yeung, H.W., 2009a. Regional development and the competitive dynamics of global production networks: An east asian perspective. Regional Studies 43 (3), 325-351.

Yeung, H., 2009b. Transnationalizing entrepreneurship: A critical agenda for economic geography. Progress in Human Geography 33 (2), 210-235.

Yin, R.K., 2012. Application of case study research. (3rd. edition), Sage, Thousand Oaks, CA.

Yu, J., Malerba, F., Adams, P., Zhang, Y., 2016. Related yet diverging sectoral systems: telecommunications equipment and semiconductors in China. Industry and Innovation, 1-23. 
Zhang, F., Gallagher, K.S., 2016. Innovation and technology transfer through global value chains: Evidence from China's PV industry. Energy Policy 94, 191-203.

Zhang, W., White, S., 2016. Overcoming the liability of newness: Entrepreneurial action and the emergence of China's private solar photovoltaic firms. Research Policy 45 (3), 604-617.

Zhang, S., Andrews-Speed, P., Ji, M., 2014. The erratic path of the low-carbon transition in China: Evolution of solar PV policy. Energy Policy 67, 903-912.

Zhang, S., He, Y., 2013. Analysis on the development and policy of solar PV power in China. Renewable and Sustainable Energy Reviews 21, 393-401.

Zhao, Z., Zhang, S., Hubbard, B., Yao, X., 2013. The emergence of the solar photovoltaic power industry in China. Renewable and Sustainable Energy Reviews 21, 229-236.

Zheng, C., Kammen, D.M., 2014. An innovation-focused roadmap for a sustainable global photovoltaic industry. Energy Policy 67, 159-169.

Zhi, Q., Sun, H., Li, Y., Xu, Y., Su, J., 2014. China’s solar photovoltaic policy: An analysis based on policy instruments. Applied Energy 129, 308-319.

Zhu, S., He, C., Zhou, Y., 2017. How to jump further and catch up? Path-breaking in an uneven industry space. Journal of Economic Geography 17 (3), 521-545. 